\title{
Vergelijkt alles en behoudt het goede : beschouwingen over onderwijs en onderzoek op het gebied van rechtsvergelijking
}

Citation for published version (APA):

de Groot, G. R. (1989). Vergelijkt alles en behoudt het goede : beschouwingen over onderwijs en onderzoek op het gebied van rechtsvergelijking. Kluwer. https://doi.org/10.26481/spe.19891005gg

Document status and date:

Published: 05/10/1989

DOI:

10.26481/spe.19891005gg

Document Version:

Publisher's PDF, also known as Version of record

Please check the document version of this publication:

- A submitted manuscript is the version of the article upon submission and before peer-review. There can be important differences between the submitted version and the official published version of record.

People interested in the research are advised to contact the author for the final version of the publication, or visit the DOI to the publisher's website.

- The final author version and the galley proof are versions of the publication after peer review.

- The final published version features the final layout of the paper including the volume, issue and page numbers.

Link to publication

\footnotetext{
General rights rights.

- You may freely distribute the URL identifying the publication in the public portal. please follow below link for the End User Agreement:

www.umlib.nl/taverne-license

Take down policy

If you believe that this document breaches copyright please contact us at:

repository@maastrichtuniversity.nl

providing details and we will investigate your claim.
}

Copyright and moral rights for the publications made accessible in the public portal are retained by the authors and/or other copyright owners and it is a condition of accessing publications that users recognise and abide by the legal requirements associated with these

- Users may download and print one copy of any publication from the public portal for the purpose of private study or research.

- You may not further distribute the material or use it for any profit-making activity or commercial gain

If the publication is distributed under the terms of Article 25fa of the Dutch Copyright Act, indicated by the "Taverne" license above, 


\section{VERGELIJKT ALLES EN BEHOUDT HET GOEDE}

Beschouwingen over onderwijs en onderzoek op het gebied van rechtsvergelijking

\section{REDE}

uitgesproken bij de aanvaarding van het ambt van gewoon hoogleraar in het recht, in het bijzonder in de rechtsvergelijking en het internationaal privaatrecht aan de

Rijksuniversiteit Limburg op donderdag 5 oktober 1989

door

MR. GERARD-RENÉ DE GROOT 



\section{VERGELIJKT ALLES \\ EN BEHOUDT HET GOEDE}

Beschouwingen over onderwijs en onderzoek op het gebied van rechtsvergelijking

\section{REDE}

uitgesproken bij de aarvaarding van het ambt van gewoon hoogleraar in het recht, in het bijzonder in de rechtsvergelijking en het internationaal privaatrecht aan de

Rijksuniversiteit Limburg op donderdag 5 oktober 1989

door

MR. GERARD-RENÉ DE GROOT 
$18 B N 9026819641$

1989 Mr. G.R. de Croot, Mastricht

Behoudens uitzondering door de Wer gesteld mag zonder schriftelijke toestemming van de rechthebbende(n) op het auteursrecht, c.q. de uitgeefster van deze uitgave, door de rechthebbende(n) gemachigd namens hem (hen) op te treden, niets uit deze uitgave worden verveelvoudigd en/of openbaar gemakt door middel wan druk, fotokopie, microfilm of anderszins. hetgeen ook van toepassing is op de gehele of gedeeltelijke bewerking.

De uitgeefster is met uitstuting van ieder ander gerechigd de door derden verschuldigde vergoedingen wan kopièren, bedoeld in artikel 17 lid 2 , Auteurswet 1912 en in het K. B. van 20 juni $1974(5 \%$. 351) ex artikel 166 . Autewrswer 1912 , te innen en/ of daartoe in en buiten reche op te tredten. 
Mijnheer de rector magnificus, dames en heren hoogleraren, dames en heren leden van het wetenschappelijk en niet-wetenschappelijk personeel, dames en heren studenten en $U$ allen die deze plechtigheid met $U w$ aanwezigheid vereert;

Gezien de spiritus loci, de sfeer dic deze ruimte uitademt, zult $U$ het mij niet euvel duiden, indien ik $U$ aan het begin van deze toespraak herinner an woorden van de apostel Paulus uit de eerste brief aan de gemeente te Thessaloniki, namelijk 1 Thessalonicenzen 5:21. Dit vers werd mij als kind steeds in een niet geheel correcte Nederlandse vertaling voorgehouden, waarwan ik de oorsprong niet heb kunnen achterhalen: "Vergelijkt alles en behoudt het goede". Indien het gebruikelik zou zijn om ter gelegenheid van de aanvaarding van een ordinariaat een lijfspreuk te kiezen, zou mijn keuze op deze variant van de woorden van de a postel zijn gevallen. Nu zulks echter niet het gebruik is, volsta ik er mee het blad van mijn oratie met deze spreuk te sieren en onder het zoëven geciteerde motto deze inaugurele rede uit te spreken.

Mijn leeropdracht omvat de rechtsvergelijking en het internationaal privaatrecht. In deze rede wil ik mij op het eerste gedeette van deze venia legendi concentreren. Daarbij zal ik achtereenvolgens stilstaan bij het onderwijs en het onderzoek op het gebied van de rechtsvergelijking. Alvorens ik dit doe, ben ik $U$ echter de beantwoording van een preliminaire wraag verschuldigd. Het is immers weinig vruchtbaar over onderwijs in een vak en onderzoek op een bepaald vakgebied te spreken, zonder aan te geven, hoe men de grenzen van dit vak ziet. Daarom zal ik nu allereerst ingaan op de vraag, wat naar mijn mening rechtsvergelijking is.

In de literatuur wordt de rechtsvergelijking op zeer uiteenlopende manieren gedefinieerd en op nog meer wijzen onderverdeeld. Mevm. Kokkini-Iatridou heeft daar in haar belangrijke boek "Inleiding tot het rechtsvergelijkende onderzoek" aandacht aan besteed. ${ }^{2}$ Met enige - terechte - ironie consta-

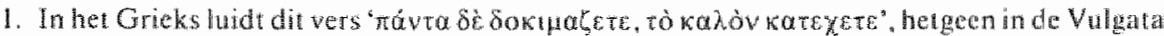
werd weergegeven met "omnia autem probatte; quod bonum est tenete". De Willibrordwertaling in het Nederlands hidt "Keurt alles, behoude het goede", terwijl de wertating van het Nederlands Bijbelgenootschap 'matar toetst alles en behoudi het goede' gect.

2. Kokkini-latridou, blz. 3-7, zie ook A.E. Orüci, Symbiosis between comparative law and theory of law, inaugurele rede Rotterdam 1982, blz. 24; wgl de kritische houding van Güner Frankenberg. Critical comparisons: Rethinking comparatiwe law, Harvard International Law Journal 1985 , blz. 411, noon $\mathbb{1}$. 
teer zij, da bija idere rechtsvergeljker zich verplich voelt "tenminsteen mieuwe onderscheiding in te vocten, hergeen usteraard de kansen op het tot siand brengen wan een consensus over de theoretische grondslagen van de rechlsvergelijking vermindert."

Op deze plads lat ik na in extenso in te gan op de merites van de diverse voorgestelde definitic en onderverdelingen. Ik volsta ermee partij te kiezen voor de volgende visie". Het is zinvol rechisvergelijking te onderscheiden in rechtsvergeliking in rume zin en rechesvergelijking in engezin. ${ }^{5}$ As latstgenoemde beschouw ik de rechtsvergehjking als wetenschappelijke methode ${ }^{\text {th }}$ discipline betreffende de systematische vergeliking wan (tegels wit) tenminste twee geldende rechtsorden. Voor deze rechtsvergeliking in enge zim kunnen uitgebreide methodologischeeisen worden geformuleerd. Dar naast kumen we ehter vele zettingen signaleren, warin personen rechtsvergelijkend bezig zijn zondar dat woorwarden dio voor de eigenlijke rechtsvergelijking gelden, in achtgenomen hoeven te worden. Te denken valt bijvoorbeeld aan rechtswergeliking in het kader van het internationaal privaatrech ${ }^{\text {to }}$ of rechisvergelijking ter vorbereiding van terminologische beslissingen bij het vertalen van juridische documentatie. "In dergelijke gevallen is wel sprake van rechtsvergeliking, mar slechts in de rume betekenis van dit begrip.

Aparte andacht verdient de vraag, of datgene wat door Rheinstein als

3. Kokkini-Iatridou, bly. 3 .

4. Lie hierower reds G.R. de Groot, WPINR $5523(1980)$, biz. 425 428.

5. Kokkini-latridou, ble. 4 sub d.

6. Zie over de vaag of rechtsvergeliking een methode of wetenschap is mel name Kok kimilatridon. blz. 7-9; vgl. verder Sauveplanne, Preadwes, blz. 3; de Sola Cañzares, blz. 100-102; Schwarz Liebermann won Wahlendor, blz. 172-174; Borislav T. Blagoyevitch, Le

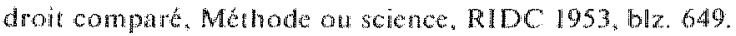

7. Kokkini-Iatridou, bl2, 13, 14; de Sola Canizares, biz. 98; Schwar Liebermann von

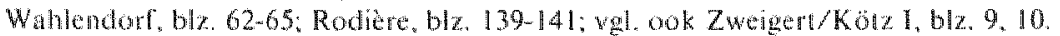

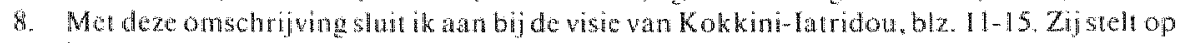

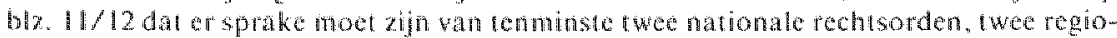

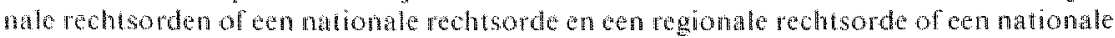
of regionale rech sorde en de internationale rechtsorde. Een vergelijking tussen (regels uit) rechiggebioden binnen én rechtsorde beschow wi wiet als rechtsvergeliking.

9. 2is over deze methodologigehe eisen onder meer Constanunesco II, bl.2.23-330; Kokkinilatritou, bla. 127-190; 2 weigert/Korz 1, blz. 31-53.

10. Datrower ondermater. Hatfol. Les apports du droit compare a droit international prive, Choix d"articles rassemblés par ses amis, Paris 1976, blz. 114 123; Yvon Loussouarn, Le roble de ta methode comparative en droit international prive français, RCDIP1979, bl2. 305-339. Arthur Taylor von Mehren. L'apport du droit comparé à la theorie et la pratique du droit international prive, RUDC 1977, biz, 493-500. Zue verder Constantinesco II. bla. 407-411, Kokkini-latridou, blz, 16-20; 2weigert/Kotz I, blz. 7, 8 .

11. Zie darover G.R. de GroolJ.P. Batkema, Recht en vertalen, Deventer 1987, blz. 15-21; zie levens G.R. de Groot, in: Kokthiniatridon, biz. 9498. 
"Auslandšrechtskunde" (de kennis van buitenlands recht) werd getypeerd ook rechtsvergelijking is. "Naar mijn mening is zulks het geval" , mar dit antwoord moet zeker nader worden toegelicht. Stel, ik wil Nederlandse juristen door middel van een lezing of een publikatie voorlichen over de inhoud van een bepaald vreemd rechtsstelsel. Dit dient dan tenminste impliciet - en liever expliciet - vergelijkend te gebeuren. Ik zal uitvoerig rekening dienen te houden met de kemnis van de toehoorders ten ananzien van hun eigen recht en zal de informatie over het vreende rechtsstelsel daarop moeten afstemmen. Verschillen tussen de desbetreffende rechtsstelsels moeten worden onderstreept en uifgewerkt en idealiter worden verklaard; overeenkomsten kunnen korter worden behandeld. Mutatis mutandis geldt hetzelfde indien ik voor buitenlandse juristen moet spreken over het Nederlandse recht. Een degelijke oriëntatic over de Empfängerhorizont der toehoorders is dan geboden. Laat ik dat na, dan praat ik over de hoofden heen, hetgeen niet slechts uit het perspectief van de methodiek van de rechtsvergelijking maar ook al op didactische gronden uit den boze is, Velen van ons zullen zich wel voorvallen herimeren, waar gedurende een lezing of tijdens de daarop volgende discussie bleek, dat de Empfängerhorizont van het gehoor onvoldoende in het oog was gehouden. Het is dan van groot belang, dat hetzij de spreker zelf hetzij een gespreksleider in de discussie alsnog rechtsvergelijkende opmerkingen maakt, waarbij de voorkennis van de toehoorders en de verstrekte informatie over het buitenlandse recht op systematische wijze naast elkaar worden gezet. De inhoud van de toespraak zal anders vaak in het water vallen, tenzij de toehoorders in staat zijn in hun eigen brein de voor het goede begrip noodzakelijke rechtsvergelijking te verrichten. Zelf zou ik echter op dat vermogen zeker bij enigszins juridischtechnische onderwerpen geen al te grote wissel willen trekken.

Als Auslandsrechtskunde zo wordt opgevat als ik zoëven heb geschilderd, kan miet worden ontkend dat zij althans tot de rechtsvergelijking in ruime zin behoort; $z \mathrm{ij}$ is een voorbeeld van impliciete rechtsvergelijking. ${ }^{14}$ Goed uitge-

12. Rheinstein, blz. 22. Volgens deze auteur noet "Auslandsrechtskunde" wotden onder scheiden van rechyswergelliking. Wel moet ook volgens Rheinstein elke rechtskergelijker zich met die "Austandsrechtskunde" bezighouden, ondat men immers pas na kennis te hebber genomen van het buitenlands recht kan vergeliken. "Auslandsrechtskunde" is in deze visic het voorportalal van de rechtsvergelijking. In deze zin eveneens o.a. Constantinesco II, blz. 129-142; Kokkini-latridou, ble. 12, 13 (met verdere bronvermeldingen); Kropholler, EPIL, wol. 10, blz. 52.

13. Zo ondermeer ook E.H. Hondius, Teachingand research in comparative law, NTIR 1977 . blz. 560-577; Sauveplanne, Rechnsstelsels, blz. 4; Zwigert/Kötz 1, bli. 13 (deze laatstgenoemde auteurs spreken in dit verband van 'deskriptive Rechtswergleichung"

14. Zie G R de Groot, WPNR 5923 (1980), blz. 426, 20 aok bijvoorbeld I. A. Jolowic\%, L"ensetgnement de droit comparế, RIDC 1988. bl 2 . 710 : "jose dire que l'enseignement d'un droit étranger ne peut guère s'imaginer s"il ne comprend pas des compasisons"; George Winterion. Comparative law teaching, A.JCL 1975, bl\%, 70: "the intelligent study of a $\rightarrow$ 
voerd wordt ze zelfs een manifestatie van rechtsvergelijking in enge zin."s Voordrachten en publikaties over buitenlands recht, die de rechtsvergelijkende dimensie - de noodzakelijke interactie tussen voorkennis van de lezers/toehoorders en de verstrekte informatie - veronachtzamen, zijn vaak tot mislukking gedoemd. Ik abstraheer nu trouwens nog even van de terminologische vertaalkundige problemen die zich aandienen, indien in een andere taal dan de bijbehorende rechtstaal informatie over een rechtsstelsel wordt verstrekt en welker veronachtzaming onder omstandigheden zelfs ernstige communicatiefouten tot gevolg kan hebben. ${ }^{16} \mathrm{Ik}$ kom daar hierna nog op terug.

In welke zin zal ik nu het begrip 'rechtsvergelijking" uit mijn leeropdracht opvatten? Zal ik me tot de rechtsvergelijking in enge zin beperken, dien ik ook de rechtsvergelijking in het kader van andere zettingen te bestuderen, moet ik me daarnaast bezighouden met Auslandsrechtskunde? In de allereerste plaats zal ik in ieder geval zelf rechtsvergelijking stricto sensu bedrijven ${ }^{17}$ en dergelijk onderzoek stimuleren. Met betrekking tot rechtsvergelijking in enge zin zall ik me verder zeker interesseren voor de theoretische vragen, die zich met betrekking tot dit vak aandienen. Ook theoretische vragen ten aanzien van rechtsvergelijking in ruime zin mogen echter op mijn warme belangstelling rekenen. Als voorbeelden daarvan vermeldde ik reeds de functie van de rechtsvergelijking in de zetting wan het internationaal privaatrecht en de plaats van de rechtsvergelijking bij het vertalen van juridische terminologie. I $\mathrm{k}$ ben echter van mening dat $U$ van mij als ordinarius in de rechtsvergelijking tevens mag verwachten, dat ik een speciale verantwoordelijkheid voel voor het tot stand brengen van publikaties en cursussen, die Nederlandse (aspirant)juristen inleiden in bepaalde vreemde rechtsstelsels. Daarnaast ben ik bereid de (mede)verantwoordelijkheid te nemen voor cursussen en publikaties, die buitenlandse juristen de gelegenheid geven kennis te maken met het Nederlandse rechtssysteem. De verantwoordelijkheid woor dergelijk onderwijs kan overigens slechts die van een primus intei pares zijn. Immers uitsluitend indien zulke programma's tesamen met andere leden van de staf afkomstig uit alle vakgroepen worden

waren legal system is difficult if not impossible without at least subconsciously comparing it to one"s owm."

15. Echter hel louter bijeengaren van materiaal uit vreemd recht is nog geen rechtswergelijking". aldus terecht Sauveplanne, Preadvies, blz. 2. Vgl, ook Arminjon/Nolde/Wolff, blz. 29, die erop wijzen, dat een werzameling win handboeken over nationale rechrsstelsets nog geen handboek over rechtswergelijking is.

16. Vgl. G.R. de Groov/M. Tragter-Schubert, Recensie van Hans Langendorf, Wörterbuch dev deutschen und niederlandischen Rechtssprache, R.M. Themis 1978 , blz $479-484$.

17. Mijn gedachten gaan daarbij primair uit naar onderzoek betreffende de common core wan de rechtsstelsels van de Europese Gemeenschap. Vgl. hierna bly. 17 
ontwikkeld, kunnen ze zowel een brede als diepgande introductic tot ons rechtsstelsel geven.

Deze laatste opmerking brengt mij op een volgend afgrenzingsprobleem met betrekking tot mijn leeropdracht. Daar deze rechtsvergelijking combineert met het internationale privaatrecht en in het perspectief van het feit, dat ik lange tijd wetenschappelijke functies vervulde op het gebied van het privatrecht, alsmede omdat ik ben ingedeeld bij de vakgroep privatrecht, zou geconcludeerd kunnen worden, dat uitsluitend privaatrechtelijke rechtsvergelijking mijn aandacht heeft. Dit zou ik hier enigszins willen tegenspreken. In de allereerste plaats zou een dergelijke taakopvatting niet erg Maastrichts zijn: juist hier aan de Rijksuniversiteit Limburg pretenderen wij immers grensoverschrijdend, thematisch te onderwijzen en onderzoek te verrichten. Het past in die visie zeker niet om me bij het bedrijven van en nadenken over rechtsvergelijking tot een van de klassieke rechtsgebieden te beperken. Met betrekking tot de rechtsvergelijking is het echter ook niet goed mogelijk de grenzen tussen de diverse juridische deelgebieden anders dan voor kennisgeving aan te nemen. Het is niet zinvol om bijvoorbeeld privaatrechtelijke, staatsrechtelijke, administratiefrechtelijke, strafrechtelijke rechtsvergelijking van en naast elkaar te onderscheiden. ${ }^{18} \mathrm{Het}$ komt niet zelden voor, dat bepaalde problemen in het ene land via het privatrecht worden opgelost, terwijl dit in het andere land via het bestuursrecht of het strafrecht gebeurt. Een vergelijking te beperken tot die regels, die in Nederland het etiket 'privaatrecht' dragen zou dan wolstrekt onverantwoord zijn. Ik zie nu nog even af van het feit, dat sommige rechtsregels in het ene rechtssysteem als privaatrecht worden gekwalificeerd, terwijl ze in het andere rechtsstelsel als staatsrecht of strafrecht worden beschouwd. ${ }^{19}$ Uiteraard kunnen we echter wel constateren, dat individuele comparatisten vaak meer dan gemiddelde kennis op een specifiek deelgebied van het recht hebben, maar een rechtsvergelijker moet een beetje van alle markten thuis zijn. "Hokjesgeest" is dodelijk voor het juridische denken: dit geldt voor de gehele rechtswetenschap, maar voor de rechtsvergelijking a fortiori.

18. Zo ook Kokkini-latridou, blz. 23, 24; Schwarz Liebetrmant von Walendorf, blz. 66-81, 255; anders kennelik M.C. Burkens, Methodologie van statsreehtelikke rechtsvergelijking, Nederlandse vereniging woor rechtsvergelijking. Nr. 19. Deventer 1975 en $Z$ walve, bla. 4.5 .

19. Zo zou een verschijnsel als ontheming wan de nationaliteit wegens hel werstrekken van walse inlichtingen in het kader van een naturalisatieprocedure kunnen worden gek walificeerd als strafrecht, burgerlijk recht, administratief rectut, stadsrech of intemationaal privaatrecht, al naar gelang de tradiic van een rechissysteem op dit punt. Vgl ook de kritische opmerkingen van Inga Markowits. Hedgehogs or foxes? a review of Westen's and Schleider's Zivilecht in Systemvergteich, AJCL 1986, blz. 118 over het begrip 'Zivilu rechl". 
Alvorens nu stil te staan bij mijn opvattingen over onderwijs in de rechtsvergelijking, is het op zijn plaars om nog kort in te gaan op de doeleinden vande rechtsvergelijking. Deze hangen immers onlosmakelijk samen met de doelstellingen, die iemand voor ogen kan hebben bij het doceren op dit vakgebied. ${ }^{20}$ Slechts op de twee naar mijn mening belangrijkste doelstellingen wil ik thans ingaan, en wel op de zogenaande "rôle èducatif" van de rechtsvergelijking enerzijds en de rechtsvergelijking met het oog op de totstand koming, respectievelijk verbetering wan hat (eigen) recht anderzijds. Herhaaldelijk is er op gewezen, dat rechtsvergelijking tot beter begrip van het eigen recht leid. Dit effect wordt soms als 'röle educatif aangeduid. Het eigen recht krijgt door de contrastwerking duidelijkere contouren. ${ }^{21}$ Vanzelfsprekende leerstukken blijken keuzen te zijn, die soms bewust maar vaker onbewust door wetgever, rechtspraak of doctrine zijn gemaakt. Onopgeloste en vaak nog niet ontdekte feilen van het eigen en van andere rechtssystemen worden zichtbar, en soms krijg je ideeen voor de oplossing van problemen uit het ejgen rechtsstelsel. ${ }^{22}$ Uit deze laatste opmerking kunt U concluderen, dat de "rôle educatif" van de rechtswergelijking en het bedrijven van rechtsvergelijking ter verbetering van het (eigen) recht inderdaad buitengewoon dicht bij elkaar liggen. De rôle éducat if van de rechtsvergelijking heeft betrekking op rechtsvergelijking in een academische context, met name in het onderwijs. Weliswaar moge bij het bedrijven van rechtswergelijking in die zetting de contrastwerking voorop staan, maar bij goed academisch onderwijs in de rechtsgeleerdheid staat - hoe dan ook - het zoeken naar zo goed mogelijk recht - wat dit dan ook moge zijn - op de allereerste plaats: hors concours! In dat kader gehanteerde rechtsvergelijking leidt daarom onontkoombaar tot de vraag, welke van de gesignaleerde oplossingen om welke

20. Met name Constantinesco; b. $2,331-431$ heeft veel andacht besteed aan de doeleinden van de rechtsvergelijking: zie hierover voorts ander meer Kokkini-latridou, blz. 26-42; Sauveplane, blz. 6-8, Schwarz Liebermann won Wahlendor, blz. 2-34; Zweigert/Konz I, bl $x_{2}$ 1431. De doeteinden, die net rechtsergelifking kunnen worden bereikt, werdeelt Constantinesco in praktische en theoret ische. Deze verdeling is echter tot op zekere hoogte willekeurig (zo ook Kokkinilatridou, blz, 27; Sehwatr Liebermann von Wahlendorf, blz. 3).

21. Vgl. Armingon/Nolde/Wolf, biz. 14-18; Constantinesco II, blz. 335, David, blz. 8, 9 ; Crobfeld, Macht wnd Ohnmach, blz, 30, 3i: Rheinstein, blz. 14, 27; Rodiere, blz. 1, 44-68; Satuveplanne, ble. 3; Schwarz Liebermann won Wahlendorf, blz. 220-221; de Solá Canizares. bla. 110; Jan Wiarda, Enkele opherkingen ower rechtsvergetijking in het algemeen, en enkele vergelijkingen tussen het Nederlandse en het Duitse en Franse priväatrecht, WPNR $4172(1951)$, blz. 2; Zweigen/Kotz, blz, 22,26.

22. Vgl. Kropholler, EPIL, wol, 10, 612, 54: Comparative law contrbutes to the improve ment of llegal education, for it provides liberatien from the narrow borders of one legal system and diteets the mind toward an abundance of other legal possibilities. It helps students of Th to achieve the necesary intellectual distance from their own system. to recognize its condicional character and to avoid a tendency to idealize it." 
reden beter is dan andere. ${ }^{23}$ Indien de docent deze yraag niet stelt, zullen goede studenten zulks hopelijk expliciet en anders wel impliciet doen. Indien we de rôle educatif van de rechtsvergelijking zo opvatten ligt deze doelstelIing nauwelijks anders dan bij rechtsvergelijking ter verbetering van het eigen recht. Deze wordt vaak onderscheiden van rechtsvergelijking ten behoeve van de wetgever, ten behoeve van de rechtspraak of ten behoeve van de advocatuur. ${ }^{24}$ Het is - dunkt me - goed om in te zien, dat het hierbij in wezen telkens om dezelfde bezigheid gaat: in al deze gevallen staat de vraag centraal, of het eigen rechtssysteem op een bepaald punt wel bevredigend is en men gaat na, hoe andere rechtssystemen deze problematick behandelen. Doelstelling daarbij is zich eventueel door in het buitenland gehanteerde oplossingen en de daarbij behorende motiveringen zo te laten overtuigen, dat men poogt deze oplossingen ook in het eigen rechtssysteen te introduceren ${ }^{25}$ Een wetgever kan zulks door wetswijziging bewerkstelligen, een rechter soms door wijziging van de tot dan toe gevolgde lijn in de jurisprudentie ${ }^{26}$ " een advocaat kan trachten door zijn pleidooi de rechter te bewegen "om te gaan", terwijl de vrouw of man van de wetenschap kan pogen wetgever of rechters te stimuleren het recht te wijzigen. Maar au fond gaat het steeds om hetzelfde: rechtsvergelijking wordt gebruikt om op ideeën te komen. Het is dan ook deze inspiratieve rol van de rechtsvergelijking die bij rechtsvergelijkend onderwijs centraal dient te staan. Tevens is het van belang bijstudenten over te brengen, dat rechtsvergelijking gewoonweg leuk is. Het is fascinerend en verrassend om - ook zonder direct doel - in vreemde rechtssystemen te snuffelen. Rechtsvergelijking heeft iets van een rommelmarkt: men slentert van stand tot stand, van rechtssysteem naar rechissysteem, om plotseling zonder daarnaar gericht te hebben gezocht, een verbluffende ontdekking te

23. Zie over de vratg naar de plats wan het wardeoordee bij rectitsvergelijkend onderzoek Kokkinilatridou, blz 176-186; Kropholler, EPIL, blz, 57, Zweigert/Kotz I, blz, 52, 53.

24. Arminjon/Nolde/Wolff, blz, 18-20; L.J. Constantinesco II, blz, 371-380; vgl. Zweigert/ Kolz I; blz. 19-22.

25. Of woorstellen lot rechtsunficatie doet, hetgeen titeindelijk ook weer lot wijziging van het eigen rechi kan leiden.

26. Ze over de invloed wan rechts vergeliking op de jurisprudentic ondermeer Ulrich Dobnig. Rechtswergleichung in der deutschen Rechisprechung, Rabels Z 1986, b/z. 610.630" Bernhand Grobfeld, Vom Beitrag der Rechtswergleichung zum deutschen Rech, AcP 1984, bli. 289-321; E.H. Hondius, Het Burgerligk Wetboek in rech ts vergelighend perspectief, in: Recht vooruit, Opstellen verzameld ter gelegenheid van 150 jaar BW. Deventer 1988 , blz. 59-71; Fréderic-Edouard Klein, L'application de la méthode comparatiwe dans la jurisprudence du Tribunal federal suisse en matiere de droit prive, RIDC 1959, blz $321-333$ : Jan Kropholler, Wissenschaft und Rechtsvergleichung. Zeitschrift fur verglechende Rechtswissenschaft 1986 , blz. 145,146 , Gert Reinhart, Rechtswergle ichung und richterliche Rechtsfortbildung auf den Gebiete des Erivat rechts, in: Richterliche Rechtsforbildung, Erscheinungsormen, Auftrag, Grenzen, Festschrift der Juristischon Fakultit zur

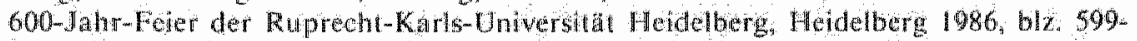
617, Zweigert/KöL 1, blz. 19-22. Vgl. over de watrde wan de rechtswergelijking voor de rechter ook de boeiende Tubinger inaugurale tede van Kontad Zweigert: Rechtsvergleichung als unversate Intenpretanonsmethode, Rabels $21949 / 50$, blz. $5-14$. 
doen. We kunnen deze bezigheid ook met een reis in vreemde landen vergelijken. Des te verder deze verwijderd zijn, des te eerder zal de reiziger de rechtsvergelijker - het exotische van de andere (rechts)cultuur voelen en door dit verveemdende effect inspiratie opdoen; naar mate je dichter bij huis blijft, worden de overeenkomsten met de eigen cultuur duidelijker, de juridische problemen en oplossingen meer vertrouwd. Maar ook heel dicht bij huis zijn er verrassende dingen, die een reis naar de buurlanden (naburige rechtssystemen) zo prikkelend en fascinerend maken.

Indien iemand rechtsvergelijking wil doceren, kan dit op zijn minst op drie, zeer uiteenlopende wijzen gebeuren. In de eerste plaats zou de docent uitvoerig aandacht kunnen vragen voor de theorie van de rechtsvergelijking. Hij zou kunnen ingaan op de vraag wat rechtsvergelijking is, de diverse doeleinden van de rechtsvergelijking kunnen bespreken, stilstaan bij de methodologische aspecten etc. ${ }^{27}$ Het is echter niet ondenkbaar, dat een dergelijke aanpak van het onderwijs interessanter en leerzamer is woor de docent dan voor de studenten. Mits gelardeerd met de nodige anekdoten ${ }^{28}$ hoeft een dergelijk onderwijs voor studenten bepaald niet saai te worden, maar ik betwijfel niettemin, of dit voldoende is om bij studenten echt enthousiasme en liefde voor het vak te wekken.

Een andere mogelijkheid om rechtsvergelijking te doceren, is het presenteren van een breed scala van rechtsstelsels in vogelvlucht, en de studenten tot een reis langs die stelsels uit te nodigen. ${ }^{29}$ Buitengewoon aardig is het om kort stil te staan bij de diverse systemen ${ }^{30}$, iets te laten zien van de historische achtergronden van die rechtsstelsels, te attenderen op onderlinge historische

27. Men vergelijke de inhoud van de in de lieraturligst wermelde boeken wan Bogdan, Constantinesco, Gutteridge, Rheinsiein en de Sola Cañizares.

28. Zie voor enkele fraaie anekdoten de autobiografie wan René David, Les avantars d"un comparatiste, Paris 1982. Zie ook H.U. Jessurun d'Otiveira, interventie nata a anleiding van thet methodologische preadvies van Sauveplanme. Nederlandse verenging voor rechtsvergelijking, Nr. 21, blz. 29 die oproept een "bistoire fantastique du droit comparêt" of een syllabus lapsorum ter lering en vermaak samen te stellen. Wellicht zou deze suggestie van d'Oliveira cens door een comparatist in ruste kunnen worden opgepakt?

29. Men vergelijke met name de inhoud var de in de litertuturlist vermelde publikattes wan David, Zweigert/Kör I en Saweplanne. Zis werder bijwoorbeld Jose Castan Tobeñas Los sistemas juridicos contemporaneos del mundo occidental, Madrid 1957, Renos Dekkers, Le droit privé des peuples, Brussel 1953; J. Duncan M. Derrett. An introduction to legal systems, Londen 1968: Mario G. Losano, I grandi sistemi giuridici. Torino 1978; Joh H. Wigmore, A panorama of the World's legal systems, 3 delen, St. Paul 1928,

30. Niet wil ik nalaten er op te wizen, dat deze anapak van de "rechtswergelijking" er dikwijls wo leid dat men zich niet bezig houdt met rechtswergelijking in de enge betekenis van dit begrip, maar 'Auslandsrechtskunde' bedrift. 
banden, alsmede in te gaan op verschijnselen als receptie van vreemd recht. ${ }^{31}$ Idealiter zal moeten worden gepoogd om enkele typische kenmerken van de te bespreken rechtsstelsels door middel van documenten te illustreren. Een nadeel van deze benaderingswijze is evenwel, dat de over te brengen kennis buitengewoon oppervlakkig blijft en aan een reis om de wereld in tachtig dagen herinnert. ${ }^{32}$

Een derde mogelijke aanpak van onderwijs in de rechtsvergelljking is studenten op te dragen zelf een stukje rechtsvergelyjkend onderzoek te doen en hen daardoor bij het veldwerk te betrekken. Deze methode heeft mijn voorkeur, hoewel ik deze onderwijsmethode wel graag combineer met enkele elementen van de vorige benaderingswijzen. Deze inhoudelijke rechtsvergelijking zie ik bij voorkeur georganiseerd in de zetting van een seminar. Aan studenten wordt gevraagd een uitvoerig schriftelijk referaat voor te bereiden over een bepaald onderdeel van een vreend rechtsstelsel. Tijdens de onderwijsbijeenkomsten gedurende de weken, waarin studenten aan hun werkstuk schrijven, wordt primair ingegaan op de moelijkheden, die men tegenkomt bij het verzamelen van en het verwerken van materiaal over buitenlands recht. Daarnaast wordt in deze periode door lezingen en de bespreking van publikaties aandacht besteed aan algemene theoretische vraagstukken, die de rechtsvergelijking betreffen. In hun referaat dienen de deelnemers een correcte beschrijwing van het door hen gekozen onderwerp uit het vreemde rechtsstelsel te geven, alsmede op verschilpunten met het eigen rechtsstelsel te wijzen. Het aantal materieelrechtelijke onderwerpen, waarover een referaat kan worden gehouden, is beperkt, zodat steeds meerdere studenten aan hetzelfde onderwerp werken, maar dit woor verschillende rechtsstelsels aitzoeken. ${ }^{33}$ Op deze wijze kunnen studenten zelf de smaak van rechtsvergelijken te pakken krijgen. Naar aanleiding van hum concrete ervaringen worden de theoretische problemen aan de orde gesteld. Doordat meerdere studenten aan éen onderwerp werken, is gegarandeerd dat intensieve discus-

31. Zie daarover onder meer Apostopoulos C. Papechistos, La recoption des droils prives errangers comme phénoméne de sociologie juridique, Paris 1975; Rheinstein, b/2. 124-127: Alan Watson, Legall ransplants, Edinburgh 1974, blz 95-101: Imre Zajay. Die Rezeption fremder Rechte und die Rechtswergleichung. AcP 1957, blz. 361-381; Imure Zajtay, Zum lisegriff der Gesamtrezeption fremder Rechte, ACP 1970, b1\%, 251-265.

32. Wel is het gemakkelijker dan bij de cerstvermelde onderwijsmothode om de door studenten verworven kennis te toetsen. Het is immers moeilijk om op een zinvole wijze te examineren over wele niteenlopende visies betrefrende theoretische vragastukken. Veal gemakkeliker is het feitenkennis te toetsen. mar wel wordt dan de wrag natr de retevantie van de parate kemnis van de te toetsen onderwerper actueel.

33. Voot het academische jaar $1989 / 1990$ worden de volgende onderwerpen owerwogen:a) de erfrectitelike positie van de langstlevende echtgenoof; b/ de medeverdache als gengige in het strafrecht; c) de regeling van adoptie van buitenlandse kinderen: d) auteursechtelike problemen bij hel samenstelen van syllabi; e) de ansprakelikheid voor onrechmatig gedrag van werknemers. 
sies ontstaan. Door echter wel meerdere onderwerpen te behandelen, wordt ook bewerkstelligd, dat de belangrijkste buitenlandse rechisstelsels herhaaldelijk opnieuw aan de orde komen.

In de zo geschilderde opzer van een seminar zall aan de meeste niet-Europese rechtsstelsels vaak onvoldoende aandacht worden besteed. ${ }^{34}$ Aanbeveling verdient derhalve, dat de docent dit hiaat iets opvult door daarop zelf in te gaan of daarvoor gastsprekers uit te nodigen. Zinvol is tevens om voor studenten, die zich in deze buiten-Europese stelsels willen verdiepen, speciale cursussen aan te bieden.

De opmerkingen, die ik tot nog toe makte over het rechtsvergelijkend onderwijs betreffen een algemene cursus rechtsvergelijking. Daarnaast bestaat er een duidelijke behoefte aan meer gespecialiseerde cursussen, die een inleiding bieden tot een bepaald rechtssysteem, gecombineerd met een introductie tot de daarbij behorende rechtstaal. Door de nog steeds toenemende internationalisering van de maatschappij en de daardoor veroorzaakte internationalisering van het juridisch verkeer ontstaat er bij juristen een stijgende behoefte aan kennis van andere rechtssystemen en het kunnen communiceren over juridische onderwerpen in een andere taal. Aan verschillende faculteiten wordt daarop enigszins ingespeeld door studenten de mogelijkheid te geven hun talenkennis te verbeteren door het volgen van cursussen. Daarnaast is het echter van belang om programma's te ontwikkelen, die behalve aan de verbetering van de taalkennis en taalvaardigheden van de betrokken cursisten in de algemene omgangstaal, in het bijzonder ook aandacht besteden aan het speciale juridische vocabulair en de bijzonderheden en specifieke taaltradities in de rechtstaal. In dit type inleidingen wordt in Maastricht voorzien door het onderwijs dat in het kader van het project Recht en Linguïstiek wordt georganiseerd. ${ }^{35}$ Deze cursussen hebben een post-graduate karakter. Daarnaast bestaan er in het eerste-fase-onderwijs door de juridische faculteit georganiseerde talencursussen (Duits, Engels, Frans, Italiaans), warrin tevens enige aandacht aan juridisch taalgebruik wordt besteed. Typerend voor de in het kader van Recht en Linguïsliek georganiseerde cursussen is dat ze zowel openstaan voor juristen als voor personen met een linguistische opleiding. Men beseffe immers, dat niet slechts juristen behoefte hebben aan inleidingen in buitenlandse rechtstalen en rechtssystemen, maar dat met name ook personen, die regelmatig juridische

34. Orcler meer vanwege het feil. dat materiaal over deze stelsels minder toegankelijk is: vgl. Zwalve, bHz. 8. Een wilzondering hierop worm de Verenigde Staten.

35. Damaver witgebreid G.R. de Groot, in: Ervaringen met problecmgestuurd juridisch onderwijs. Deventer 1989, bz. 125-140. De in het kder van Recht en Linguistiek georganiseerde cursussen worden gegeven door de furidische faculteit van de Rijksumiversitein Limbutg in samenwerking met de in Marstricht gevestigde Rijkshogeschool Opleiding Tolk/witaler. 
teksten moeten vertalen daartoe een sterke noodzaak voelen. De cursussen Recht en Linguïstiek combineren een inleiding in een vreemd rechisstelsel met een inleiding in de bij dat rechtsstelsel behorende rechtstaal. ${ }^{36}$

Hoe staat het nu met de belangstelling van studenten voor rechtsvergelijkend onderwijs? De interesse voor specifieke inleidingen in het recht en de rechtstaal van bepaalde landen is groot. Slechts weinig Maastrichtse studenten tekenen hier echter in voor een algemene cursus rechtswergelijking. De redenen daarvoor zijn tenminste tweeërlei. In de eerste plaats moet rechtsvergelijking in de keuzevakkensfeer concurreren met vele andere vakken. Nu de studieduur tot vier jaar is bekort, verliest een vak als rechtsvergelijking bij het keuzecarrousel dikwijls van vakken die studenten om de een of andere reden als volstrekt onmisbaar en zeer gunstig voor de arbeidsmarke beschouwen. ${ }^{37}$ Een tweede grond voor het geringe antal studenten, dat besluit rechtsvergelijking te kiezen, is echter van nog meer gewicht. In toenemende mate worden studenten gestimuleerd om een gedeelte van hun studietijd in het buitenland door te brengen, zulks ondermeer doorvanwege de Europese Gemeenschap geinitieerde subsidieprogramma's. ${ }^{38}$ De studenten, die zich door zulke programma's naar het buitenland laten lokken, zijn in de regel de potentiele klanten van de docent rechtsvergelijking. Doordat deze studenten evenwel reeds een stukje van hun studie in het buitenland doorbrengen, blijft minder tijd over om zich aan hun thuisuniversiteit ook nogeens in de rechtsvergelijking te verdiepen. Bovendien wordt de buitenlandse studieperiode

36. Deze cursussen omvatten een inkeiding tot de instituties van een rechtstelsel, alsmede een behandeling van enkele rechisgebieden (bjwoorbeeld verbintenisssenrecht, rechtspersonenrecht, zakenrecht). De bij dat rechtsstelsel behorende wreemde taat is werktaal. Naast het verwerven wan juridisch-inhoudelyke kennis stat het oefenen van taalwaardigheden centraal. Luisterwaardigheid en spreekvaardigheid worden geoefend lijdens de lezingen en de daarop volgende discussie. Aan de hand van opdrachten, zoals het vertalen van coniracten, hel schrijuen van brieven en het schriftelijk samenvatten van teksten, worden schrijfvardigheid en leestardigheid geofend. Voorts word aandacht besteed ann specifike terminologische en fraseologische problemen. Er wordi toved mogelik gewerk atan de hand van authentiek materiaal.

37. Zo ook Karl Neumayer. Rechtsvergleichung als Unterrichtsfach, Festschrift lür Konrad Zweigert, ble, 507-512; George Winterton, Comparal be law teaching, A.JCL 1975, bl\%. 98 .

38. Met name door het zogenaamde ERASMUS-programma, dat op 15 juni 1087 door de Rad van de Europese Gemeenschappen werd angenomen. Daarower onder merer R. W. Jagtenberg. $1992 \mathrm{en}$ het juridisch onderwijs, A.AE 1989, blz. 510,511 en Chiara Zilioli, The recognition of diplomas and its impact on educational policies, in: Bruno de Witte (ed.), European Community Law of Education, Baden-Baden 1989, b/z. 65-69. Zic verder A.3. Alvarez, European Legal Studies, Een international sudicprogramma, Onderzok van onderwijs $1989, b 12$. 40, die er onder meer op wijst, dat uitwisselingsprogramma 's in de praktijk dikwijh moelijkheden ondervinden doorde sterk wieenlopende wizen van duur en indeling van het academisch jaar. Zij roept op om deze problematiek mel prioniteil in Brussel aan te karten, zodat van daaruit enanzet wond gegeven tot enige harmonisatic wan academische jaren. Bij deze oproep sluit ik mij van ganser harte aan! 
terecht als rechtsvergelijkende ervaring gezien. ${ }^{39}$ Deze ontwikkelingen zijn boeiend en moeten worden gestimuleerd. Wel is het een belangrijke taak van de thwisuniversiteit om de uit te zenden studenten zo goed mogelijk voorbereid aan hun studieperiode in het buitenland te laten beginnen. Opdat de studenten een optimaal rendement wit hun buitenlands verblijf halen, is witeraard in de eerste plaats nodig, dat zij travel survival kits voor rechtsvergelijkers in hun rugzak hebben. Alvorens op reis te gaan moeten zij reeds goede kennis over het eigen rechtsstelsel hebben, waartegen ze de nieuw te verwerven kennis kunnen afzetten. Voorts dient verzekerd te zijn, dat de talenkennis van de studenten op een goed niveau is. En ook moeten deze studenten al enig inzicht hebben in de voetangels en klemmen op het gebied van de rechtsvergelijking, alsmede een zekere inleidende kennis over de plaats van het te bestuderen rechtsstelsel tussen andere rechtsstelsels.

Zoëven liet ik het woord 'uitwisselingsprogramma 's" vallen. Het verkeer met de partneruniversiteiten is geen eenrichtingsbeweging: er komen ook studenten wan buitenlandse zusterfaculteiten naar Nederland. ${ }^{40}$ Juist deze studenten blijken ondermeer belangstelling voor een vak als rechtsvergelijking te hebben. Dit heeft de opmerkelijke consequentie, dat het onderwijs in de rechtsvergelijking voornamelijk door buitenlandse studenten wordt bijgewoond, terwijl de Nederlandse studenten hun rechtsvergelijkend onderwijs bij buitenlandse collegae volgen. Voor de docent rechtsvergelijking is dit overigens bepaald niet onplezierig: zeker bij de zoëven geschetste seminaropzet kan optima forma rechtsvergelijking worden bedreven. Voor de participerende Nederlandse studenten versterkt de aanwezigheid van hun buitenlandse collegae "den Duft der großen weiten Welt", als U me toestaat in dit verband een oude Peter Stuyvesant-reclameslogan van de Duitse TV te citeren.

Overigens ben ik van mening, dat aan deze buitenlandse studenten, die als gevolg van een ERASMUS-uitwisseling of binnen een ander kader een gedeelte van hun studie aan cen Nederlandse juridische faculteit volgen, in elk geval ook een inleiding in het Nederlandse recht moet worden aangeboden. We mogen deze unieke kans om de bekendheid van het Nederlandse recht in het buitenland jets te vergroten, niet onbenut voorbij laten gaan. ${ }^{41}$

39. Het is niet onatig te vermelden, dat het aameal juridische studenten, dat vanuit Maastrich een aantal maanden aan een buitenlandse partnerutiversiteit gat studeren. niet ona nzienlijk is. In 1988 makkten 22 studenten van deze nogelijkheid gebruik, in 1989 7ullen dit e circa $45 \mathrm{zijn}$. Als de huidige tendens zich woortzet, zullen in 1992105 studenten in uil wisselingsprogramma $\mathrm{s}$ participerev.

40. In Mastrichr volgden in 198816 buitenlandse juridische sudenten op deze basis enige tijd onderwijs, in 1989 zullen dit er circa 25 zijn, terwijl dit aantal naar werwachting in 1990 col 35 zal groeien.

41. Het Nederlandse recht is voor buitenlandse juristen tamelijk ontoegankelijk. Dit ligt - 
Tot nog toe sprak ik over speciale programma"s, waarin rechtsvergelijkend onderwijs wordt gegeven. De vraag moet echter worden gesteld, of de internationalisering van de maatschappij en van het recht niet met zich mee behoort te brengen, dat het gehele juridische onderwijs in rechtsvergelijkend perspectief moet worden gegeven. Moet niet tenminste de stof van het einddoctoraalonderwijs ${ }^{42}$ telkens een wergelijking zijn van de oplossingen van het eigen rechtsstelsel met die van andere rechtssystemen? Bij de beantwoording van deze - retorisch bedoelde - vraag wil ik me aansluiten bij het standpunt van $Z$ weigert $/ \mathrm{Köt} \mathrm{Z}^{43}$ : "die Ergebnisse der rechisvergleichenden Forschung müssen in den nationalen Rechtsunterricht integriert werden. Das heißt: das konkrete Problem wird zunächst an den aktuellen Lösungen der bedeutenden Rechtsordnungen in seiner Fülle sichtbar gemacht; es folgen kritisch wägende Überlegungen, welche Lösung für unsere eigene Gesellschaft hic et nunc die beste ist. So erhält die aktuell im nationalen Recht herrschende Lösung ihr volles Profil, und nur so wird der Sinn für Reform und Verbesserung des Rechts geschärft und in die Verantwortung gestellt . . Das bedeutet schließlich, daß die 'nationalen' Lehrbücher auf rechtsvergleichendem Hintergrund neu geschrieben werden und da $B$ auf längere Sicht alle Rechtslehrer die vergleichende Methode beherrschen müssen, um sich die notwendigen Informationen aus eigener Kraft zu beschaffen. ${ }^{, 44}$

Bijzondere vermelding verdient in dit verband een programma, dat door de Juridische Faculteit van de Rijksuniversiteit Limburg wordt ontwikkeld in samenwerking met de Universiteit Lancaster"s: European Legal Studies

- onder meer ook a an het feit, dat er geen bibliografic van vreemdtalige publikaties over het Nederlands recht bestaat. Het ligt evein wel in mijn voomemen om in het kader wan het Maastrichtse project Recht en Linguïstiek een infotheek "Dutch law in foreign languages" te creëren. Vgl. over het nut van kennis van het Nederlandse (privaat)recht voor builenlanders: G.J.W. Steenhoff, Nar een Europees privaatrecht, in: J.B.J.M. ten Berge e.a. (red), Recht als nom en ats aspiratie, Nijmegen 1986. blz. $98-100$.

42. Vermelding verdient ook de opmerking van R. W. Jagtenberg. A Ae 1989, bl\%. 512 dal nuet. valt in te zien "warom bijwoorbeeld in de propacdeuse niel ook meteen nat ander recht dar geldend Nederlands tech gekeken zou kunnen worden. In feite word dit reeds jarten gedaan, namelijk bij het onderwijs in het Romeins recht."

43. Zweigert/Köla , bla. 25

44. Zic ook E.H. Hondius, Van Naderlands recht natrechl in het algemen, NJB 1985, 1343; Zo eveneens C. Flinterman, Europa 1992, Nedenlands recht en juridisch onderwijs, Publiek Domein 1988, blz. 85.86. Vgl. woorts Kropholler, EPIL, vol. 10, blz. 54, 55: Becase of its significance comparative law should not only be offered in special classes for the interested, but the results of comparative legal research should also be an integral part of the material presented in regular courses dealing wh individual branches of law."

45. Van de Universiteit van Trenlo (Italie) is een intentieverklaring ontwangen, wat rin wondt gesteld dat zijaan het ELS-curriculum will deelnemen. Voorts participeent ook de Universiteit van Trier (BRD), zij het dat deze universiteit wooralsnog wel studenten zat ontvangen. maar niet zelf studenten zal wizenden. Een acieve participatie van een Duitse universitcil stuit monentel nog op grote moeilijkheden vanwege het feit, dat een aspiran-jurist - 
(ELS). ${ }^{46} \mathrm{Na}$ tweeeneenhalf jaar aan de eigen faculteit te hebben gestudeerd, wordt de student die het ELS-programma volgt gedurende anderhalf jaar met rechtsvergelijkend opgezette 'blokken' geconfronteerd. Een half jaar volgt de student ELS-blokken in zijn eigen faculteit, maar in deze blokken participeren tevens buitenlandse ELS-studenten. De beide andere ELS-periodes worden gevolgd aan in ELS samenwerkende buitenlandse faculteiten. Blokken die momenteel in samen werking door docenten van de participerende faculteiten worden ontwikkeld zijn: Company, Trust, International Trade, alsmede Media. Elke faculteit geeft de daar te doceren vak ken in haar eigen (rechts)taal. Gedurende de eerste tweeèneenhalf jaar worden de ELSstudenten aan hun thuisfaculteit speciale cursussen aangeboden, die ten doel hebben hen de voor het volgen van vreemdtalig onderwijs in het einddoctoraal benodigde taalkennis en taalvaardigheid bij te brengen. Deze cursussen besteden speciale aandacht aan juridische terminologie. Indien een Nederlands student het ELS-programma met succes heeft gevolgd, verwerft hij de titel Meester in de rechten. Buitenlandse studenten krijgen een corresponderende graad van de uitzendende (eigen) universiteit. ${ }^{47}$ Dit ELS-curriculum is een goed voorbeeld van een poging om de juridische studie te internationaliseren door in de eindfase van de studie rechtsvergelijkend opgezet onderwijs te geven. ${ }^{48}$

Nu het derde millenium van onze jaartelling nadert, past het echter om te vragen, of de tijd langzamerhand niet rijp is voor een principiële herstructurering van de juridische studie. ${ }^{49}$ De rechtenstudie is in Nederland - en

- zijn academische studie in Duitsland moet afsluiten door een staatsexamen. Een langdurig verbliff aan cen buitenlandse juridische faculteit wordt darom door vee studenten niet als adequate voorberciding voor dat examen gezien. Opmerkelijk is in dit verband een recente uitspraak wan de Hessische Statsminister Karl-Heinz Koch, Die Juristenausbildung braucht neue Wege, Zeitschrift für Rechtspolitik 1989, bla. 283. Naar aanleiding van de vrata, of het statsexamen moet blijwen bestaan, merkt hij op: 'Wäre es nicht vielleicht unter dem großeren Horizont Europas an der Zeit, diesen etwas provinziell wirkenden Sthim doch einmal zuzukiappen?". Zie verder Heinhard Steiger, Deutsche Juristenausbildung und das Jahr 1992, Zeit schrift fur Rechtspolitik 1989, bl2. 283-287. Vgl. ook reeds Grobfeld, Macht and Onnmadh, blz. $16,17$.

46. Zie over he ELS-programma witwoerig: A J. Alvarez, European Legal Studies, Een internationaal studieprogramma, Onderzoek van onderwijs 1989. blz. 39-41.

47. Zo zullen Engetse studenten de grad Bachelor of European Legal Studies (B.E.L.S.) verwerven.

48. Interessant is ook, dat King"s College in London en Paris I reeds meer dan tien jarten een gemeenschappelijk atriculum hebben ontwikkeld. Studemten volgen achterenvolgens iwe jaren in Engeland cursussen in common law en bestuderen daarna twee jaren in Frenkrijk Frans rech. Zijgroeien derhalve in twe juridisclie culluren op en verwerven ook twee titels (LL. B. in Londen en de Mautrise in Parjis). Wgl. Andre Tunc, L'enseignement du droit compare. RIDC 1988, blz. 706, alsmede Xavier Blanc-Jouvan, Réflexions sur l'enseignement du droit compare, RIDC 1988 , blt $758,759$.

49. Vgl. Karl H. Neumayer, Rechtsvetgleichung als Unterrichtsfach, Festschrif für Konrad Zweiger, Tubingen 1981, blz. 505: 'Juristen, welche gegernwärig an den Universitäten hhre Ausbildung erfaher, werden ihre Berufstätigkei hauptsachlich im 21. Jahrhundert - 
hetzelfde geldt voor tenminste de andere Europese staten - buitengewoon national-gericht. Het verwerven van kennis en vaardigheden met betrekking tot het eigen nationale rechtsstelsel staat voorop; de plaats van vakken als Europees recht en rechtsvergelijking is marginaal, hoewel deze vakken gedurende de laatste decennia wel in de diverse curricula territoir winnen. Door dit 'provincialistische' karakter ${ }^{50}$ van de rechtenstudie is ook de feitelijke waarde van de zo verworven juridische titels, graden en andere beroepsqualificaties in de meest letterlike zinvan het woord begrensd. De erkenning van deze qualificaties blijkt in het buitenland aanzienlijke moeilijkheden op te leveren. ${ }^{5 / 3}$ Vroeger was dit anders. Tot de negentiende eeuw was het heel gewoon, dat juristen van het ene land naar het andere trokken om aan daar gevestigde universiteiten rechten te studeren. Dit blijkt, indien we de curricula vitae van bekende juristen of de alba studiosorum van universiteiten bestuderen. ${ }^{52}$ In het universitaire onderwijs stond destijds niet de nationale regelgeving centraal maar het gerecipieerde Romeinse recht, dat - in elk geval in geheel continentaal Europa - als "ius commune" werd ervaren. De codificaties die sinds het eind van de achttiende eeuw zijn gerealiseerd hebben daaraan een einde gemaakt. ${ }^{93}$ Sinds nagenoeg twee eeuwen zijn jurtsten navelstaarders geworden, die slechts over de grenzen kijken indien het werkelijk niet anders kan. De rechtswetenschap werd to nationale wetenschap. ${ }^{54}$

$\rightarrow$ ausuben. Bewor sie ihre Altersgrenze erreichen, wird das positive Recht, indem site einst unterwiesen wurden, sich in groBen Teilen in die Rechisgeschichte verabschiedet haben. Sie werden daher genötigt sein, sich immer wieder der Ermeuerung dew Rechisstoffes anzupassen. Dies wird ihnen eine solide Rechtskultur und jene Flexabilität des Rechisdenkens abverlangen, für deren Vermitulung die Rechtsvergleichung unentbehthich ist."

50. Deze term ondeen ik aan Sawveplanne, preadvies, blz. 3, die over "rechisprovinclatisme" spreekt. Vergelijk ook de unspraak wan André Tunc ... die de rechtsvergelijking als een 'sortir du néolithique' ziet of de uitspraak wan Schwarz Liebormann von Wahlendorl, ble. 222: "Le droit comparé ... a pour tâche d"assurer que "les théologiens du droit" ne soient pas victimes d'une "esprit de chapelle".

51. Daarover H. Schneider. Een klein stapje in de richting vanechte "Europese" juristen?, AAe 1989. blz. 368-374.

52. Vgl. René David. Practiciens du droü el droill comparé, in: Konlliki und Ondnung. Festschrift für Murad Ferid zum 70. Geburtstag. München 1978, b1\%, 451, 452; 2walve. ble. 13 en 16.

53. Zie daarover onder meer $\mathrm{J}$ E. Spruit, Romeins rech, Terugblik en uitzicht, Nieuwenhoflezing 1, Deventer 1988, blz. 9-11. Ook het feit dat het Latijin zijn functie als "lingua fra nca" voor juristen verloor, speelde cen rol bij de ondergang van een "Europese" rechuswetenschap. De gedachte van een "ius commune" is voorts nadelig beinvloed door en veel geciteerde uitspragk van Montesqieu, Esprí des lois, Amsterdam/Leiptig 1769, boek I. hoofdstuk 3: "Les lois politiques at civiles de chaque nation... doivent etre tellement propres au peuple pour lequel elles sont faites, que cest un grand hazard si celles d'unc nation peuven convenir à une autre."

54. Vgl reds de woorden van $\mathbb{R}$ udol won thering, Geist des römischen Reehts, deel 1, lode druk, Aaten 1968, blz. 15: Die Recht swissenschaftist zur Landesjurisprudenz degradiert. die wissenschaftlichen Grenzen fallen in der Jurisprudenz mit den politischen 2 usammen. Eine demütigende, unwürdige Form fü eine Wissenschaft.' Daarover Grobfeld. Macht und Ohnmacht, blz. 15 met verdere literatuurverwijzingen. 
In den wreemde rechten studeren werd een bezigheid voor extravagante geesten en politieke viuchtelingen. ${ }^{55}$ Deze situatie is - nu we op de drempel van de eenentwintigste eww staan - onhoudbaar, zeker in en Europa waar we cen toenemende economische, sociale en politieke integratie van de diverse nationale staten kunnen constateren. ${ }^{56}$ Het is noodzakelijk, dat we tenminste bij de juristen binnen de Europese Gemeenschap - opnieuw een gevoelen van een "ius commune" scheppen. ${ }^{37}$ In de eerste jaren van een rechtenstudie in n"importe welke lidstat van de Europese Gemeenschap zou aandacht moeten worden besteed aan datgene, wat de rechtssystemen van de diverse staten gemeen hebben. ${ }^{38}$ Beginnende studenten dienen behalve met vakken als rechtsgeschiedenis, metajuridica, economie en dergelijke kennis te maken met het Europese institutionele recht, Europees privaatrecht, Europees staatsrecht, Europees administratief recht en Europees strafrecht ${ }^{59} \mathrm{Bij}$ deze laatsigenoemde wakken dienen de gemeenschappelijke grondslagen van het recht van de lidstaten van de EG centraal te staan en niet meer de nationale particularismen. Een dergelijke aan pak van het rechtenonderwijs zal de communicatiebasis tussen de in de diverse lidstaten opgeleide juristen aanzienlijk verbreden en de juristenmobiliteit - zowel tijdens als na de studie vergroten. Bovendien zal het feit, dat de juridische opleiding zich iets distantieert van de details van de nationale rechtssystemen juridische kennis opleveren, die minder sterk door één pennestreek van de wetgever veroudert. ${ }^{60}$

55. Men denke bijwoorbeeld aan de vele Duitse juristen van lloodse origine die vanar 1933 hun toevlucht in met name Anglo-Amerikanse landen hebben gevonden.

56. Vgl ook Meinhard Hill, bl2. 48: "The more the European States cooperate and become interdependant on each other, the nore common solutions to commonly experienced problems must be fournd... A comparative approach is essential for the effective implementation of Communty law within the member States and thus for the developmenn of a law which is felt to be a jus commune throughout the Community', alsmede Clive Schmithof, Die kunfigen Aufgaben der Rechtsvergleichung, JZ 1978, bl2, 498, 499: "Wir brathchen eine völlige Unstellung der allgemeinen juristischen A usbildung, die die Dimension der EWG und darüberhinaus der Welt im ganzen einbeziehen muB.' In deze zin ook: Heithard stetger, Deutsche Juristenausbildung und das Jahr 1992, Zeitschrift fü Rechtspolitik 1989. bl2. 284. Zie ook de recente nota 'Onderwijs en Wetenschappen en de Europese interne mark" (Kamerstuk 21217 , d.d. 14 juli 1989).

57. Val ook R.W. Jagtenberg, Ae 1989, bl., 512, die betoogt dat "het Europese integratie. proces praktijkjuristen nodig makt die minder "Neerlando-centrisch" zujn opgetejd da tot duswerre an Nederlandse universieiten wellicht gebruikelijk was."

38. Om in de terminologic van Zwalwe, b/2. 9 te spreken: het is nodig on juist de essentialia, die de Europese rechisstelsels verbinden, te benadrukken en an de accidentalia, die de verschillen tussen de stelsels bewerkstelligen, minder aandacht te besteden. Vgl. J.H.M. van Erp. Europees privatrecht in ontwikkeling, in: A. A. Franken e.a. (red.), Themis en Europa, 2wolle 1989, blz. 67; G.J.W. Steenhof, Naar een Europees privaatrecht, in: J.B.J.M. ten Berge e.a. (red.), Recht als norm en als aspiratie, Nijmegen 1986, blz 101.

59. Vgl. Cess Flintarman, Publek Domein 1988, bl $z, 86$ die voorstelt om in elke lidstat van de EG woralsnog éen "Faculté de droit européen' te scheppen, war wordt opgeleid to: 'meester' in het Europese recht op basis van een studieprogramma, waarin het 'klassieke' Europese recht en de rechtsvergehiking central stan.

60. Ein Sirich des Gesetzgebers und ganze Bibliotheken werden zur Makulatur. 
Graag wil ik op deze plaats nog enkele nadere opmerkingen maken over dit onderwijs, dat zich op de gemeenschappelijke grondslagen van het recht van de lidstaten baseert. Met deze gemeenschappelijke grondslagen bedoel ik de 'common core": datgene wat de diverse rechtsstelsels gemeen hebben. "Deze "common core" bestaat uit diverse componenten. In de eerste plats denke men aan de vele beginselen en regelingen, die de stelsels gemeenschappelijk hebben, daar ze zijn voortgekomen uit dezelfde historische wortels, met name uit datgene wat vroeger als "ius commune" werd ervaren. ${ }^{62}$ Maar er is intussen meer: door internationale verdragen, maar vooral door $\mathrm{EG}$-verordeningen en richtlijnen zijn aanzienlijke gedeelten van het recht der lidstaten van de EG geuniformeerd, althans geharmoniseerd: we kunnen hier een ius commune nieuwe stijl signaleren. ${ }^{63}$ En vergeten we voorts niet de ha rmoniserende invloed van de rechtspraak van het Europese Hof van de Rechten van de Mens bij de interpretatie van de Europese Conventie van de Rechten van de Mens: werd de Marckx-beslissing van dit Hof niet door Sir Gerald Firzmaurice als 'a whole code of family law' betiteld? ${ }^{64}$

\section{Er is - dunkt me - voldoende 'ius commune' aanwezig om het curriculum} van een juridische opleiding te vullen. Een essentiële vraag is evenwel door middel van welk materiaal studenten met dit gemene recht kennis kunnen maken. Het is noodzakelijk om nieuwe leerboeken te ontwikkelen, waarin de

61. In dit onderwijs betreffende de gemeenschappelijke grondslagen (conmon core) der Europese rechtsstelsels zou wal Rodolfo Sacco als circulatie van doctrimaire en jurispradentiële modellen typeert een belangrijke rol kunnen spelen (Rodolfo Sacco, Droit commun et composantes du droit, in: Cappel lett, Common perspectiwes, blz. 95-109\%.

62. Vgl. Helmul Coing, European common law: historical foundations, in: Cappelletti, blz. 31-44. Gewezen zij in dit verband op de opmerkelijke postdoctorale, "weejarige 'Scuola di specializzazione in comparazione giuridica su base romanistica" onder leiding van Prof" Giovanni Pugliese aan de Universita di Roma "La Sapienza". Vgl tewens de opmerkingen van Zwalve, blz. $\| 0-20$ over het Romeinse recht ats tertium comparationis bij de vergelijking van het privaatrecht van de Europese staten. De he rstructurering van de rechtenstudic op de ther voorgestane wijze werpt nicuw licht op de positio wan het Romente recht. Daarover J.E. Spruit, Romeins recht, Terugblik en uizich, Nieuwenhoflezing $\bar{I}_{\text {, }}$ Deverter 1988, ble. 26, 27: "in het gestage proces wan het terugdringen vibn hel belang wan de nationale grenzen, hell afbreken van muren en andere obstakels dic de tol de Europese gemenschap behornde landen gescheiden houden, landen warin in een nog nibt zo ver achter ons liggend verleden het Romeinge recht het praktisch ius commune bij titstek was. zou door middel van een qua on wang beheerste matr in $k$ waliheit vol watadiga confronlalie met het Romeinse recht aan de Europese jeunesse dorebebefen inzich kumen worden bijgebrach omtrent hetgeen ons aan overgeerfd rechisgoed, nationale grenzen ten spijt. verbonden houdt. Het bied bij uitstek mogelijkheden tal van gemeenschappelijke roormen en warden in onze westerse rechtscultur in cen wroegstadium van de studie te accentueren."

6.3. Geattendeend zij verder onk op bijvoorbecld he Wense Verdragenverdrag wan 23 nei 1969 (Trbl. 1972,51 ), warin zich gemene grondslagen van verbintenissenrecht manifesteren.

64. Registry of the Court Council of Europe, Strasbourg 1979, Marckx Case Judgment of 13

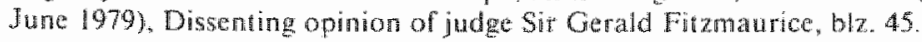


common core van de nationale rechtsstelsels centraal staat. Over de opzet van dexe nieuw te ontwikkelen leerboeken wil ik $\mathrm{Köt} \mathrm{t}^{65}$ aan het woord later:

'Dabei kăme es entscheidend darauf an, die Materie von vornherein unter einem europaischen Blickwinkel darzustellen. Es darf also nicht von einer bestimmten nationalen Systematik ausgegangen, es darf nicht ein bestimmter nationaler Leserkreis angesprochen und es darf nicht in erster Linie die Absicht werfolgt werden, auf diese Weise zur Verbesserung eines bestimmten nationalen Rechts beizutragen. Ein solches Lehrbuch müBte vielmehr von Anfang an einen Standpunkt jenseits der nationalen Rechtsordnungen einnehmen, und es müBte, soweit nötig sein eigenes System und seine eigenen Begriffe entwickeln. Dies ist sicherlich eine schwierige Aufgabe, aber die rechtsvergleichende Forschung hat inzwischen einen Stand erreicht, der mich zu der Hoffnung ermutigt, daß diese Aufgabe nicht unlösbar is. ${ }^{\circ 6}$

We kunnen Kötz slechts bijvallen, waar hij stelt, dat het schrijven van dergelijke leerboeken moeilijk is. Belangrijk voorwerk is op menig gebied echter al verricht. Wat het privaatrecht betreft ${ }^{67}$ zij gewezen op het tweede deel van het magistrale werk van Zweigert en Kötz, 'Einführung in die Rechtsvergleichung auf dem Gebiete des Privatrechts" ${ }^{48}$, waarin algemene privatrechtelijke leerstukken rechtsvergelijkend in kaart worden gebracht. ${ }^{69}$ De aandacht zij voorts gevestigd op het onlangs verschenen tweede deel van 'Europäisches Privatrecht' wan Coing, waarin het continentaal-Europese privaatrecht tussen 1800 en 1914 wordt geschetst. ${ }^{70}$ Beide werken

65. Neue Aufgaben der Rechtsvergleichung, Juristische Blatter 1982, blz. 362; zie eveneens Köz, Gemeneturopäisches Zivilrecht, Festschrift fur Konrad Zweigert, Tubingen 1981 , blz, 498-500; zo ook Jan Kropholler, Zeitschrift fïr vergleichende Rechtswissenschaft 1986, bl. 155, 156, G.J.W. Steenhoff, Naar een Europees privantrecht, in: J B.J.M. ten Berge e.a. (red.), Recht als norm en als aspiratie, Nijmegen 1986, blt. 90.

66. Vigl. over ervaringen met bet ontwikkelen van een rechtsvergelijkend-autonome systematiek en dito rechtsbegrippen bij het opzetten van de International Encyclopedia of Comparative Law: Ulrich Drobnig, Methodenfragen der Rechtsvergleichung. lus Privatumin Gentum (Festschift für Max theinstein) 1. Tübingen 1969, b/2. 228-233.

67. Voor het publiekrecht kunnen belangrijke bouwstenen worden onteethd aan T. Koopmans boek ove "Vergelijkend publiektech" (Deventer 1986). Wat het besturstecht betreft geven onder meer enkele recente publikaties uit Tilburg goede hoop op cen rechtsvergelijkende a ampak van het administratieve recht (bijvoorbeed J.P. de Jong. Bestumbrech wan vreemde herkomst, Zwolle 1988, A.J.C. de Moor, Algemene beginselen wan behoorligk bestum en butenlandse equivalenten, Zwolle 1987; A.K. Koekkoek, Adninistrative law and the constitution in Ireland and the Netherlands, Preadvies Nederlandse Vereniging voor rechtsvergelijking. $N$ r. 38, Deventer 1987). Strafrechtelijke auteurs zouden te rade kunnen gaan bij de rechtsvergelijkende monografiebn wan het Freiburger Max Planckinstitut fur auslandisehes und internationales Strafrecht en bij een werk als "Rethinking Criminal Law" van de hand van George Fletcher (Boston/Toronto 1978),

68. Band II: Institutionen, tweede druk, Tubingen 1984.

69. Uit dit werk blijkt ook duidelijk, dal ook de continentaal-Europese en Anglowamerikanse stelsels een dudelijke common core hebben.

70. Helmut Coing, Europâsches Privatrech, Band 11, 19. Jahrhundert, Uberblick uber die Entwicklung des Privatrechts in den ehemals gemeinrechtlichen Ländern, München 1989. 
bevatten belangrijke grondstoffe voor auteurs van een leerboek over Europees privaatrecht. Verdere bouwstenen zouden auteurs kunnen ontlenen aan "restatements" van Europees recht naar Amerikaans model", waarin op rechtsvergelijkende basis "Europese" regels en beginselen worden ontwikkeld en toegelicht. ${ }^{22}$

\section{De rechtsvergelijkende opleiding van Europese aspirant-juristen zou circa} tweeeneenhalf jaar mogen duren. Daarna stel ik mij een kopstudie voor, die deze personen in statat stelt zich hetzij in te werken in het lokale recht of zich op een andere wijze te specialiseren. Deze kopstudie dient nauw aan te sluiten bij de reeds gevolgde algemene opleiding. ${ }^{73}$ Het hier beschreven model heeft het evidente voordeel, dat een jurist die reeds een vierjarige juridische opleiding in een lidstaat van de EG heeft gevolgd, door een anderhalfjarige vervolgopleiding in een andere lidstaat zich ook daar voor het juridische praktijkleven zou kumnen qualificeren. ${ }^{74}$

71. Zie over de wenselijkheid van zulke restatements: Kötz, Juristische Bläter 1982, b12. 362 , alsmede Kötz, Festschrift für Zweigert, blz. 495-498. Vgl ook J.H.M. van Erp Europees privaatrech in ontwikkeling, in: A. A. Franken e.a: (red.). Thenis en Europa, Zwolle 1989, blz. 61, 62; G.J.W. Steenhoff, Naar een Europees privatrecht, in: J. B.J.M. ten Berge e.a. (red.), Recht als norm en als aspiratie, Nijmegen 1986, 61z. 87,88.

72. Zie op dit gebied de opmerkelijke activiteiten van de Commissie Europecs Contractenrecht, die reeds de eerste concepten over regels betreffende nakoming van we tbüntenissen en de gevolgen wan niet nakomen heeft opgesteld, watrover Ole Lando, European Contract Law, A.JCL 1983, b42, 653-659. Deze auteur beschrifft de opzet van dese Europese "restatements" als volgt: "As in a statuste each rule or principle is stated as an article. As in the American Restatements it is accompanied by a comment stating the reasons for the rule, its purpose, operation, and relationship to other rules. The operation of the rule is also explained by the use of illustrations. In a note to the rule its background and source are mentioned, be it the common ciore of the legal systems of the Member States. one or several of the existing laws of the States, an international convention, the American Uniform Commercial Code, or some other source." Zie verder Kropholler, Zeitseltrift für vergleichende Rechtswissenschaft 1986, bilz. 155, 156; Ole Lando, A contract law for Europe, International Business Lawyer 1985, blz. $17-21$.

73. In deze context dient ook te worden gewezen op de rechtswergelikende opzet wan curricuIum wan de juridische faculteit te Trento, en ERASMUS-partner van Madricht. Hitrover will ik Rodolfo Sacco. Enseignement de droil compare, RiDC $1988,63 \%, 726$ a a n het woord laten: "La factié qui se distingue de toutes les aures est la Faculte de Trente. Lat ila philosophe qui a présidé l'élaboration du plan d'érudes est celle-ci: que l'on peut faire preceder l"etude de droit compare, el faire suivre l"étude du droit local. ... A Trente. chaque enseignement est donné sur deux bases, sur la bage du droit comparé é sur la bàse municipale. L"étudiant est letissé libre de choisir phutôt des matieres de droit muncipal ou plutôt létude de droit compare. Malgré cette liberté les systentes sont malière obligatotre pour tous les étudiants de prenière année. Lexanen sur les systemss est un examen cardinal."

74. Bij het ontwikkelen van juridische curricula die abstraheren van het rechl van eden bepalde rechtsorde is hel tuttig om kennis te nemen van de ervaring in de Verentigde Stateh: L.M Friedman/G. Teubner. Legal education and legal integration: Europesn hopes and American Experience, in: M. Cappellett, Integration through law, wol. 1 Methods, tools and integration), book 3 (Fores and potential for a European identity), Berlin 1986, blz. 345-380. Op deze publikatie wijst ook R.W. Jagtenberg. AAe 1989, bl2. 513. Zue ook - 
Na de zoeven gemaakte opmerkingen over onderwijs in de rechtsvergelijking, wil ik thans stilstaan bij onderzoek met betrekking to de rechtsvergelijking en bij thet rechisvergelijkende onderzoek zelf. I $\mathrm{k}$ gaf reeds aan, dat de theoric van de rechtsvergelijking nog steeds een tamelijk onderontwikkeld gebied is; weliswaar bestan er nogal wat publikaties waarin bepaalde theoretische $k$ westies worden besproken, maar over vele vragen is een communis opinio nog ver te zoeken. ${ }^{\text {ps }}$ Het nadenken over deze theoretische vragen behoort tot het onderzoeksgebied wan een ordinarus in de rechtsvergelijking. Een van de meest interessante kwesties met betrekking tot deze theorie van de rechtsvergelijking ${ }^{76}$ vind ik persoonlijk - het zal U niet verbazen - de problematiek van het vertalen van juridische teksten. Deze problematiek vormt een van de centrale problemen van de rechtsvergelijking. Indien men immers over een bepaald onderwerp bijvoorbeeld het Nederlandse recht wil vergelijken met het Duitse en Franse recht en het resultaat van zijn bevindingen in het Nederlands wil publiceren, dan zal men de inhoud van de desbetreffende regelingen uit de beide buitenlandse rechtsstelsels (vergaand) ${ }^{77}$ in de Nederlandse juridische terminologie moeten weergeven. Dit kan onder omstandigheden uitermate moeilijk z̈jn. Bestudering van dit kernprobleem van de rechtsvergelijking is van groot belang om goede adviezen te kunnen geven aan diegenen, die rechtsvergelijkende publikaties woorbereiden. Het resultaat van dit onderzoek is trouwens ook van belang voor diegenen die niet rechtsvergelijkend werken, maar - bij het afronden van een dissertatie - wel met de verplichting van een vreemdtalige samenvatting van hun onderzoek worden geconfronteerd. ${ }^{8}$ Te weinig wordt door juristen beseft, dat het nakomen van deze verplichting rechtsvergelijkend onderzoek naar de te hanteren terminologie impliceert. Vele samenvattingen blijken terminologisch onzuiver te zijn en nog meer samenvattingen schieten dermate langs de Empfängerhorizont heen, dat de kosten en moeite voor een dergelijke samenvatting ook hadden kunnen worden bespaard. In goede vreemdtalige samenvat tingen bij proefschriften ligt trouwens een schat van rechtsvergelijkende terminologische ervaring verborgen, die tot nog toe niet systema-

- Flinterman, Publate Domein 1988, blz. 86; Hondius, NJB, b12. 1343. Vgl. over bet lunctioneren van Amerikange juristen buiten de VS de volgende publikaties: Kelley Chorles Crabb, Providing legal services in foreign countries: making room for the American atomey, Cohmbia Lat Review 1983, bla 1767-1823; Roger J Goebel, Professional qualification and educational requirements for law practice in a foreign country: bridging the cultural gap. Tulane law review 1989 , ble. 443.523 .

75. Zo ook kokkini-tatridou, bla, 3-7.

76. Die onder meerdoor Kokkini-latridou, blz. 8,9 mi. terecht als zelfstandige deeldiscipline wordi beschouwd. Anders Zwalwe, bl $2,6,7$.

77. Soms zal voor een niet-vertalen vat gevonden begrippen moeten worden gekozen. Daarover G.R. de Groot, in: Kokkini-latridot, blz, 96, 97.

78. Zo bijvoorbeld art. 30 lid 2 van het promotiereglement wan de Rijsuniversiteit Limburg. Weliswarkan mendit karwei aan anderen uitbesteden, mar het verdient sterke aabbeveling zelf tenminste wat de terminologie betreft te assisteren. 
isch is opgedolven. Toegegewen zij, dat met het delven van deze schat witeraard veel menskrach gemoeid is.

Bij uitstek is onderzoek naar de problematiek van her vertalen van juridische terminologie echter van belang voor personen, die in hun dagelijks werk worden geconfronteerd met de noodzaak juridische informatie over een rechtsstelsel weer te geven in een andere taal dan de aan dat rechtsstelsel gerelateerde rechtstaal. Ik denk daarbij in de eerste plaass aan juridische vertalers, maar ook de bij het grensoverschrijdende juridisch verkeer betrokken juristen moeten dikwijls op deze wijze vertalen ${ }^{79}$ De bestudering van deze op de theorie van de rechtsvergelijking betrekking hebbende vraagstelling is derhalve bepaald niet slechts van theoretisch belang, maar heef wooral ook een niet te onderschatten praktische dimensie. Het is verbazingwekkend, dat op dit gebied dat nauw samenhangt met de vraag of een thesaurus van comparatieve begrippen kan worden ontwikkeld en hoe een dergelijke thesaurus optimaal kan worden gerealiseerd, nauwelijks research is verricht ${ }^{80}$ Met betrekking tot deze problematiek is het onderzoeksklimaat in Maastricht buitengewoon gunstig door de aanwezigheid van de Rijkshogeschool, Opleiding tot Tolk/Vertaler. Het bedoelde onderzoek zal de theoretische basis van de reeds vermelde cursussen Recht en Linguïstiek versterken. U mag derhalve in de naaste toekonst hier in Maastricht research op dit gebied verwachten. In elk geval zal ik zelf op dit gebied actief zijn. Bovendien is al een eerste promovendus begonnen aan een dissertatie op dit terrein. ${ }^{81}$ Een eerste schaap is dus al op de dam; er zal naar ik hoop en verwacht nog een hele kudde volgen, die behouden de andere zijde van de dam, die naar deze aula leidt, zal bereiken. Ik zal mijn best doen om - wellicht geassisteerd door enkele collegae - als een goede herdershond voor deze kudde op te treden.

\section{Behalve het onderzoek op het gebied van de theorie van de rechtsvergelijking}

79. Vgl Henry de Vries, The international legal profession, International Lawyer 1987, bl. 851: "The law professional in international transactoon is primarily an interpreter. a channel for communication between and among formally organized legal systems with differing national histories and experiences, raditions institutions and customs."

80. Zie Kokkini-1atridot, blz. 90-93. Deze te onwikkelen rechtsvergelijkende thesaurus hangi m.i. naw samen met hel voorstel van Wolfgang Mincke, Eine vergleichende Reclitswissenschaft, Zeitschrift hir vergleichende Rechtswissenschaft 1984 , blo. $328 \mathrm{om}$ cen specifieke taal te ontwikkelen warin rechtssystemen kunnen worden beschrever. De comparatieve begrippen zijn wermoedelijk ook identick met het begrippenapparat, dat Kotz nodig ach voor de beschrijung van niet aan de terminologie en systematiek wan mationale rechtsstelseis gebonden rechtsvergelifkende beschouwingen, watrover hier boven op bl2. 18, alsmede voetnoot 66 .

81. Het desbetreffende dissertatieonderzoek betreft de problematiek wan het vertalen wan juridische teksten in het algemeen. Overigens ligt hed in het woornemen om in december 1990 een symposum te organiseren over de problematiek wan het vertalen van juridische terminologie. De tijdens dat symposium te presenteren papers zullen begin 1991 bij Kluwer. Dewenter verschijnen onder de titel 'Recht en vertalen II'. 
is er natuurlijk het rechtsvergelijkende onderzoek zelf. Dit onderzoek neemt tegenwoordig een belangrijke plaats in bij het rechtswetenschappelijke onderzoek. Vele studies op het gebied van burgerlijk recht, strafrecht, staats-en administratief recht etc. hebben $z 0^{3} n$ rechtsvergelijkende dimensie. ${ }^{82}$ Kennelijk zijn vele onderzoekers van mening, dat het minder zinvol is te proberen nieuwe ideeên op hun vakgebied te ont wikkelen, zonder kennis te nemen wan ontwikkelingen en opvattingen in het buitenland. ${ }^{83}$

Steeds mindet Nederlandse juristen kiezen voor een academisch kluizenaarschap in de grot van het eigen rechtsstelsel. Uiteraard kan zo'n kluizenaar door intensieve studie en meditatie tot belangwekkende inzichten komen, maar mij zou telkens - als ik me even probeer in te leven in die kluizenaar het angstige gevoel bekruipen dat iemand butten de grot misschien reeds lang diezelfde goede inzichten of zelfs nog betere heeft gehad. En zau ik dat achteraf ontdekken dan zou ik mijn meditatief geploeg en gezwoeg als verspilde tijd beschouwen. We moeten ons trouwens afvragen, of er zuiver objectief bekeken, niet ook daadwerkelijk sprake is van verspilde tijd, als men zich aftobt over problemen en daarvoor oplossingen vindt die door anderen reeds lang zijn aangedragen. Niet slechts van uit het perspectief van een bepaald persoon kan dan sprake zijn van verspilling van energie, ook vanuit het perspectief van de maatschappij is het spijtig als personen onafhankelijk van elkaar - zonder kennis te nemen van elkaars gedachtengang - zich buigen over dezelfde, althans nauw verwante problemen. Een rechtseconomische analyse van de kosten van het naast elkaar bestaan van talloze rechtssystemen, waartussen nauwelijks, althans uitermate slechte commu-

82. Sommige publikaties zijn uitdrukkelijk rechtsvergelijkend van aard, doordat zil aparte hoofdstukken wijden aan de afzonderlike bestudeerde rechtsstelsels of andersans systematisch wergelijken. De meeste "rechtsvergelijkend" getinte werken bevatten echter uitsiu" tend uitstapjes naat vreemd recht, "als dit nuttig is om een standpunt te onderstrepen waar in hat Nedertands rechi nog lacunes bestann." (aldtns: L. Bier. Aansprakelijkheid voor bedriftsongewalen en beroepsziektem, Deventer 1988, biz. 13).

83. Op deq plaats zll herinnerd an woorden wit 2 weigert/Kötz, blz. 13: 'Kene Wissenschaf kann es sich leisten, stch allein auf Erkenninisse zu stützen, die innethatb ifrer nationalen Grenzen produziert worden sind. Nur die nationalen Rechtswissenschaften haben sidi lange mit der 'in nernationalen' Diskussion begnugt und betreben das zu einem guten Teil heute moch. Aus diesen unhalbar gewordenen Zustand fuhrt die Rechtsergletchung herats und damit hinein in eine internationale Rechtswissenschaft. "Vgl. ook de Beleidsnotitie "Internationalisering van onderwijs en onderzoek" (kamerstuk 20217, blz, 10): Voor wetenschapsbeoefening geld dat ze intrinsuek international van karakter is. Onder roek dragt bij ande vergroting wat het mondiale reserwoir an kentis. Anderzijds is thet woor de onderzoker noodzakelik atert te zijn op en ansluiting te hebben bij de ontwikklingen in het internationale kennisreservoir."

84. Her beeld wan de "grot" ontleen ik aan de fitel van een opstel wan cen bekend Amerikans rechtsvergeliker van Nederlandse afstamming: Hessel Yutema, Looking out of the caves, Michigan Law Review 1956, blz. 899. De titel van het opstel wan Yntema is weer duidelik ingegeven door de zogenaande "Dialoog van de grof" van Plato. 
nicatie bestaat, lijkt me - hoe speculatief een dergelijke studie uit de aard der zaak zou moeten zijn - de moeite waard.

Het kiezen voor of tegen de rechtswergelijking is een kwestie van mentaliteit: kiest men voor de grot of voor de wereld daarbuiten? Wil men zelf het buskruit uitvinden - al is het wellicht ook elders reeds ontdekt - of voelt men zich content indien men van een buitenlandse expeditie teruggekomen de formulle van het buskruit in zijn rugzak heef? Vindt men reizen heerlijk, of beschouwt men reizen als een zich noodzakelijk verplaatsen van plats $A$ naar plaats $B ?^{85}$ Kiest men in het kader van een onderzoek woor een rechtsvergelijkende expeditie, dan is een volgende vraag, hoe untvoerig deze expeditie zal moeten worden opgezet. Niet steeds zal een reis om de wereld zinvol zijn. We moeten ons een variant op de woorden van de Prediker voor ogen houden: er is geen einde a an het maken van vele reizen en veel doorvorsen is een afmatting voor het lichaam. ${ }^{86}$ Uiteraard kan niet worden uitgesloten, dat het rechtsstelsel van Hawai, Japan of Nieuw-Zeeland voor bepaalde problemen uiterst attractieve oplossingen hebben bedacht. Rechtsvergelijkers in hart en nieren zullen graag hun koffers pakken om zulks te controleren. Maar de kosten van dergelijke excursies moeten tegen de potentiêle bäten worden afgewogen: we moeten in de gaten houden, dat expedities veel tijd en geld kosten. Tenzij we daarom door de bestudering van literatuur of anderszins redenen hebben om aan te nemen, dat andere rechtsstelsels een bepaalde materie beter hebben uitgewerkt, ligt het voor de hand de rechtsvergelijking in eerste instantie tot naburige landen te beperken ${ }^{87}$

Voor Nederlandse juristen umpliceert dit een vergelijking met het recht vän België. Duitsland, Engeland en Frankrijk. Het op deze landen betrekking hebbende materiaal is voor Nederlandse juristen zowel feitelijk als qua taal het meest toegankelijk. Door de juridische literatuur van deze landen te bestuderen, nemen we bovendien indirect ook kennis van ideeën en opvattingen, die zich buiten deze staten ontwikkelen. We weten, dat de Duitse academische literatuur tevens de Zwitserse en Oostenrijkse publikaties redelijk in het $o \circ g$ houdt en door zorgvuldige bestudering van de Engelse literatuur ook de ontwikkelingen in andere common law jurisdicties niet geheel buiten het vizier zullen blijven, mits deze belangwekkend zijn. Rechtsvergelijkende expedities naar het recht van onze buren lijken me derhalve voor vrijwel elk onderzoek voor de hand te liggen, waarbij het overigens van de aard van het onderwerp en de ter beschikking staande tijd

85. Het zal geen toewal zijn, dal de meeste rechtswergetijkers verwoede reizigers en lezers van reisgidsen en reisverthalen zin.

86. Vgl Prediker 12:12.

87. Vgl. ook Kokkini-latridou, blz. 138, 139, die er voor warschuw rechtsvergelijkend onderzoek al te breed op te zetten. 
afhangt, of het zinvol is om ook het common law-system van Engeland in het onderzoek te betrekken.

In her kader van de kosten/baten-analyse van de rechtswergeliking past het om nog kort nader stil te staan bij de kluizenaars in de grot. Uhoort mijniet beweren, dat alle kluizenaars uit de grot moeten worden gejaagd. Menige beslissing kan zonder meer worden genomen op basis wan de know how, die in de grot is geaccumuleerd. Buitengewoon nuttig is het voorts, dat deze opgehoopte kennis wordt gesystematiseerd en toegankelijk gemakk. Met name ook degenen die deel uitmaken van rechtsvergelikkende expedities zijn daarbij gebat, daar zijalvorens de grot te verlaten heel goed moeten hebben bestudeerd, hoe de te onderzocken problemen in het eigen rechtsstelsel worden opgelost.

Intussen heb ik hier in Mastricht weinig reden tot klagen. Een onlangs in onze faculteit gehouden mini-enquêtetje leerde mij, dat het gros van de Maastrichtse onderzoekers bezig is met cen onderzoek dat een rechtsvergelijkende dimensic heeft. Dit feit heeft consequenties voor de taak van degene die aan deze universiteit rechtsvergelijking als primair aandachtsveld heeft. Hij dient bereid te zijn deze onderzoekers - in zeer nauw overleg met hun primaire begeleiders en promotores - te adviseren, indien zij bij hun rechtsvergelijkend onderzoek problemen ontmoeten. Hij dient er ook voor te zorgen, dat er een forum is, waar deze onderzoekers hun ervaringen op het gebied van de rechtswergeliking kunnen uitwisselen. ledereen die ervaring heeft met rechtsvergelijkend onderzoek weet immers, dat het dikwijls niet eenvoudig is om zich in we werken in andere rechtsstelsels. Het is daarom uitermate nuttig om van (zowel positieve als negatieve) ervaringen van collegae te leren. Daarom is het goed om enkele werkgroepen te vormen, waarin onderzoekers die rechtsvergelijkend werkzaam zijn hun ervaringen uit wisselen. Het ligt darbij voor de hand om "landengroepjes" te vomen. ${ }^{88}$ De bijcenkomsten van deze landengroepen kunnen bovendien een belangrijk clement vormen van de onderzoekersopleiding die aio"s dienen te hebben, indien zij rechtsvergelijkend onderzoek verrichten. Het komt mij voor, dat ook nog andere maatregelen kunnen worden genomen om onze alo's en anders onderzoekers beter te equiperen voor hun rechtsvergelijkende reis, die zij zullen moeten ondernemen. Allereerst dienen zijkennis te maken met enige van de vraagstukken die tot de theorie van de rechisvergelijking mogen worden gerekend. Een dergelijke kennismaking zou kunnen geschieden in

88. Ik denk datrbij primair an werkgrocpen voor onderzoekers, die zich bezighouden mot onderzek betrefende België, Bondsrepubliek Duitsland Groot-Brittannie. Frankrijk, respectievelijk de Verenigde Staten, alsmede aan cen "restgroep" voor personen, die 0 .a. ook het rech wan nog andere landen begtuderen. Deze werkgroepen zouden tenminste eenmall per twee manden bijeet moeten komen. 
een van de landengroepen losstaande werkgroep Rechtsvergelijking. Daarnaast komt het mij voor dat de in het kader van het project Recht en Linguïstiek aangeboden landencursussen voor beginnende onderzoekers een uitstekende introductie kunnen vormen tot de rechtssystemen die zij zullen moeten bestuderen. Om optimaal geschikt te zijn voor jonge onderzoekers zouden deze cursussen nog iets kunnen worden aangepast, maal zulks is geen bezwaar daar het toch al in de bedoeling ligt het cursusaanbod in het kader van het Recht en Linguïstiek-project te verbreden. ${ }^{89}$ Uiteraard ben ik mij ervan bewust, dat dergelijke cursussen niet echt goedkoop zijn. Maar m.i. loon zich een dergelijke investering met het oog op de resultaten van het onderzoek. Het zal U overigens duidelijk zijn, dat ik de bedoelde cursussen ook graag zou zien aangeboden aan de aio"s van zusterfaculteiten.

Het is tegenwoordig niet eenwoudig in een Nederlandse bibliotheek rechtsvergelijkend onderzoek te verrichten. Er is gewoonweg te weinig geld om in voldoende mate materiaal met betrekking tot het buitenlands recht aan te schaffen. Uiteraard zou ik nu kunnen stellen, dat derhalve meer geld ter beschikking moet worden gesteld voor de opbouw en instandhouding van juridische collecties. Maar indien ik de baret die ik thans draag voor een andere pet verwissel, die ik buiten deze aula ook zou mogen opzetten, weet ik dat het daarvoor benodigde geld althans hier aan de RL, en m.m. geldt hetzelfde voor onze zusterfaculteiten, niet in voldoende mate aanwezig is. We zullen dus naar andere mogelijkheden moeten zoeken. De belangrijkste mogelijkheid heet 'coördinatie van het aanschaffingsbeleid". Bijna acht jaar geleden heeft de Groep Juridische Bibliothecarissen door het instellen van een Commissie Collectievorming met het oog op allerlei toen dreigende bezuinigingen getracht een dergelijke coördinatie in het aanschaffingsbeleid ten aanzien van buitenlandse publikaties te stimuleren. Deze coördinatiepoging heeft relatief weinig vruchten afgeworpen. ${ }^{90}$ Het is derhalve nodig om

89. In elk geval zou ook andacht moeten worden besteed aan bibliografisch onderzock, allsmede an parlementaire documentatie in het bijzonder in verband met de behandeling van wet sontwerpen. De cursussen, die mij woorogen staan zouden idealiter moeten worden algestoten met een zorgvildig voorbereide excursie nan het land in $k$ westue. Deze excursio zou in elk geval moeten omvatten een bezoek aan het parlement, an de hoogste rechterlijke instanties a an een of meerdere ministeries, alsmede an een universiteit. De cursusleiding zou moeten garanderen dat de deelnemende aio"s in ell geval aan de te bezocken uniwersiteit ook gesprekken kunnen voeren met iemand die enig inzich hech op het onderwerp, dat hen in de naaste tokomst slapeloze nachten zal bezorgen.

90. Een belangrijk resultaat van de activiteiten van deze commissie is evenwel de CCJP (Centrale Catalogus buitenlandse Juridische Periodieken. Warwan in 1988 een 1 weede druk verscheen (T.M.C. Asser Instituut, "s-Gravenhage). De eerste druk van deze calalogus werd in 1985 gepresenteerd als hulpmiddel bij de voorgenomen landelijke coördinatie van collectievorming inzake butentandse periodicken". In het voorwoord bij de tweede druk wordt opgemerkt, dat de effecten van de CCIP voor de coordinatic van de collectie. worming gering gebleken zijn (blz. XII). Op de blz. 150-157 worden de namen van - 
opnieuw actie te ondernemen on te bewerkstelligen, dat in Nederlandse bibliotheken een goede en brede collectie material met betrekking tot buitenlands recht aanwezig is. De collectioneringsafspraken dienen niet slechts betrekking te hebben op periodieken, maar op de totale collectie met betrekking tot buitenlands recht. Bij deze coördinatie dienen bibliotheca rissen, bibliothekcommissies en diegenen, die een primaire verantwoordelijkheid hebben met betrekking tot het onderwijs en het onderzoek betreffende de nhet-Nederlandse rechtssystemen, nauw samen te werken. Bij de te maken collectioneringsafspraken moet met de geografische situatie van een universiteit in Europees perspectief heel goed rekening worden gehouden. De Rjjksuniversiteit Groningen dient te beseffen slechts fl. 198,80 retour eerste klas van het in Continentaal-Europa voor privaatrechtelijk onderzoek niet te overtreffen Max-Planck-Institut für ausländisches und internationales Privatrecht in Hamburg verwijderd te zijn; de Katholieke Universiteit Nijmegen kost het fi. 154,20 (retour) om naar de in Münster aanwezige boekentempets te reizen. Voor Maastricht liggen de prijzen nog gunstiger: $f, 22,60$ woor België indien men een frankophone omgeving kan verstaan; voor een Nederlandstalige omgeving is de prijs $\mathrm{f} 1.53,00$. Voor Duitsland zal men komend vanuit de Limburgse hoofdstad f1. 81,20 moeten investeren, indien men tenminste in Keulen een universiteitsbibliotheek met een grote juridische collectie wil bezoeken. Voor meer eenvoudige vragen is $\mathrm{fl}, 32,40$ voor een retourtje naar Aken voldoende. Voor een reis Maastricht-Londen is het vliegtuigtarief fl. $298,-$.

De kosten die verbonden zijn aan het willen bestuderen van buttenlands recht kunnen nog omlaag, indien goede afspraken worden gemaakt over het interbibliothecair leenverkeer. Momenteel is het interbibliothecair leenverkeer dusdanig ingericht, dat eerst wordt nagegaan of de benodigde publikatie elders in Nederland voorradig is. Pas daarna wordt onderzocht, of dit werk wellicht in een buitenlandse bibliotheek aanwezig is. Met name dicht bij de grens gelegen universiteiten zoals de Rijksuniversiteit Limburg zijn er echter bij gebaat, dat een intensief en snel interbibliothecair leenverkeer met de dichtbij gelegen buitenlandse universiteiten ontstaat." Bij het maken var:

* juridische periodicken vermeld, die wel in de Index to legal periodicals of de lndex to foreign legal periodicals worden verwerkt mas riet in Nederland aanwezig zijn. In dit verband (b/2, 149) wordi opnieuw tot coördinatie van collectievorming op het punt wan buiterilandse periodieken aangespoord. Dewe oproep ondersteun ik van harte in het belang wan het rechtsvergelijkend onderzok in Nederland.

91. In Mastricht worden overigens dard werkelijk stappen in deze richting gezet. Ex bestaat eet Euregional bibliotheckoverleg mer de UB's in Luik en Aken. In de naaste toekomst wordt in dit overleg wellicht ook nog Hasselt betrokken. Het ligt in de bedoeling om in de Eurego met onderling interbibliothecair leenverkeer de landelijke circuts the doorbreken. Zeer veetbelovend is een ont werp voor een Euregional Library Network dat in het kader van het EG-actieplan voor bibliotheken via de NBBI bij de EG mer een subsidie- - 
landelijke coordinatieafspraken met betrekking tot de te collectioneren periodieken en boeken kan vervolgens ook rekening worden gehouden met de collecties van die universiteiten en idealiter zouden deze universiteiten bij het maken van de afspraken moeten worden betrokken. Wel is in dat geval natuurlijk noodzakelijk, dat de gebruikers van én der bibliotheken van de samenwerkende universiteiten via de computer loegang hebben tot de catalogi van de andere bibliotheken.

Waar we kunnen constateren dat universiteiten zich tegenwoordig niet meer kunnen permitteren om bijzonder breed te collectioneren en derhalve collectioneringsafspraken geboden zijn, moet worden onderstreept dat de aanschaffing van een bepaalde categorie boeken in elke bibliotheek die rechtsvergelijkend onderzoek mogelijk wil maken noodzakelijk is. Ik doel op (juridische) bibliografieèn. In de eigen bibliotheek moet op betrouwbare wijze kunnen worden vastgesteld, welke literatuur in andere staten is gepubliceerd. Buitenlandse documentatiebronnen vergelijkbaar met de Nederlandse Data Juridica zijn in elke wetenschappelijke juridische bibliotheek onmisbaar. Om een zo breed mogelijk rechtsvergelijkend onderzoek mogelijk te maken, zou ik willen verdedigen, dat alle bibliografieën van dit type dienen te worden aangeschaft, voor zover zil gesteld zijn in voot ons ook maar enigszins toegankelijke talen. Deze bibliografieën openen voor de comparatist de wereld; zonder deze is hij visuleel gehandicapt.

Intussen mag een nieuwe ontwikkeling niet onvermeld blijven. In toenemende mate kunnen zulke bibliografieèn ook on line" worden geraadpleegd.92 Het is derhalve theoretisch denkbaar om zittend achter een com-

- verzoek is ingediend Een dergelijke voorkeurssamenwerking met betrekking tot interbibliothecair leenverkeer opent yoor de toekomst duidelijke perspectieven yoor collectioneringsafspraken op rechtsvergelikend gebied. Het is immers evident dat het profiel van de rechtsvergelijkende collectie van de Rijksuniversiteit Limburg moet worden bigeswold, indien kan wordengegarandeerd, dat bepadde publikaties binnen ben a wee dagen uit een naburige bibliotheek Maasirich kumen bereiken. Het bijstellen van het profiel wan de collectie dient dan wel in nau overleg met de zusterfaculteten, c. gusterbibliotheken te geschieden, opdat kan worden bewerkstelligd dat gezamenlijk een zo breed mogelijk gebied word gedekt. Intussen is het spijtig, dat het furegionat overleg zich wooralshog niet uitstrekt tot een Duitse UB met een woor en juridische faculteit bestemde collectie.

92. Het is echter vaak bepald niet eenvoudg te achterhalen, we ke (gurdische) biblografiedi op deze wije kunnen worden geradpleegd en wiat welke "host" dit kan gebeuren. Belangrijk is derhalve het inthatief van de werkgroep Jundisehe informatie wan de VoGIN (Vereniging voor Online Gebruikers in Nederland) om te komen tet een Gouden Cids van buitenlandse juridische databestanden. Opgenomen worden itiel, onschijving van de database en bronnen, de producen, de hostonganisathe, adres, foul, geografiseh gebled, updating. Het verschinen van deze Engelstalige Gouden Gids is voo rechtsvergelikers over de gehele wereld van groot belang. Op de publikatie ervan wooruitopend 2 al in decembet 1989 een door mevr. mr. Angelique Bessems gemat kte inventarisatic verschinten van de butenlandse juridische databestamden die kunen worden geraudploegd via de host-organisaties, warbij de Rikstuniversiteit Limburg is angestoten. 
puter in Maastricht bibliografieen betreffende vele rechtssystemen te raadplegen. Dit klinkt echter mooier dan het is. De structuur van de zo te raadplegen databanken verschilt vaak niet onaanzienlijk, terwijl ook de gehanteerde computertalen herinneringen aan Genesis 11 oproepen en last but not least word de onderzoeker gehinderd door het verschil in rechtstaal en in de regel ook in linguistische taal. Hier past een: comparatisten aller landen, verenigt $U$ ! Het zou voor rechtswergelijkend onderzoek, d.w.Z. voor de grensoverschrijdende communicatie tussen juristen ideaal zign, indien men zittend achter een computer in Maastricht of waar dan ook ter wereld via een uniforme thesaurus nief slechts toegang zou kumnen verkrijgen tot Nederlandse on line te raadplegen bibliografieèn, maar ook tot de bibliografieèn van andere rechtssystemen. Opnicuw moet ik overigens constateren, dat de verwerkelijking van deze droom door het ontwikkelen van een systeem van comparatieve begrippen zou worden bevorderd. ${ }^{93}$

Voor goed rechtsvergelijkend onderzoek heeft men niet slechts buitenlandse juridische literatuur nodig, maar ook jurisprudentie, wetteksten en wetsontwerpen met daarbij behorende parlementaire stukken. M.m. kunnen over de jurisprudentie en wetteksten dezelfde opmerkingen worden gemaakt als over de literatunr. Indien een bibliotheek niet in staat is om buitenlandse jurisprudentie en wetteksten aan te schaffen, moet in elk geval worden gegarandeerd, dat men in de eigen bibliotheek het bestaan van relevante jurisprudentie en wetten kan ontdek ken, zodat ze gericht kunnen worden opgevraagd: dit impliceert weer de aanwezigheid van goede bibliografische informatie. Ook hier openen de ontwikkelingen voor wat betreft de on line raadpleging van bestanden voor de rechtsvergelijker de mogelijkheid van een schier paradijselijke infrastructuur, maar ook hier moet nog veel gebeuren voordat de werkelijke infrastructuur dermate is bewerkt, dat enige parkstructuur zichtbaar wordt. De huidige situatie kan eerder met een oerwoud worden vergeleken, waarin sommige bomen en struiken aantrekkelijke bloemen en vruchten dragen.

Nagenoeg ontoegankelijk blijken vaak buitenlandse wetsontwerpen en de daarbij behorende parlementaire stukken te zijn, terwijl juist deze documenten woor comparatisten zulke interessante informatie bevatten. In andere landen aanhangige wetsontwerpen manifesteren mogelijke ontwikkelingen van de desbetreffende rechtssystemen, de daarop betrekking hebbende parlementaire stukken maken in de regel iets van de achtergronden van die mogelijke ontwikkelingen zichtbaar, zij tonen de maatschappelijke of juridisch-technische coulissen, die het nodig maken om legislatief op te treden. Ook nadat wetsontwerpen tot wetten hebben geleid blijven die parlemen-

93. Kokkini-Jatridou, Preadwies, blz. 13. 
taire stukken van eminent belang voor het goede begrip van de ontstaansgronden van wettelijke bepalingen. Zij maken zichtbaar tussen welke oplossingen is getwijfeld en om welke redenen woor welke oplossing is gekozen. Parlementaire stukken zijn ewenwel buitengewoon omvangrijk en dienovereenkomstig kostbaar. Het komt derhalve weinig voor, dat een bibliotheek beschikt over de parlementaire stukken van een andere staat, latat staan dat een bibliotheek beschikt over de parlementaire documentatie van meerdere staten. Het zou een enorme stimulans voor de rechtsvergelijking betekenen indien deze documentatie met betrekking tot buitenlandse rechtssystemen toegankelijk zou worden. Gezien de toenemende onderlinge verstrengeling van de rechtssystemen van de lidstaten van de EG zou het prioriteit hebben een documentatiecentrum over wetsontwerpen en bijbehorende parlementaire stukken van de lidstaten van de Europese Gemeenschap op te richten. Via een systeem van trefwoorden zou deze documentatie moeten worden ontsloten. Het raadplegen van dit - meertalige - trefwoordensysteem zou uiteraard ook 'on line' moeten kunnen gebeuren. Het zou voorts mogelijk moeten zijn om kopieën van benodigde documentatie bij het centrum te bestellen. Het bestaan van een dergelijk documentatiecentrum zou een harmoniserend effect op de wetgeving in de diverse lidstaten van de EG hebben, daar wetgevers (en wetenschappers) veel eenvoudiger dan thans het geval is, kunnen kennis nemen van elkaars legislatieve ideeën, alsmede dikwijls van de bijbehorende argumenta pro en contra. ${ }^{94}$

Tot nog toe sprak ik over maatregelen die zouden moeten worden genomen om de infrastructuur voor rechtsvergelijkend onderzoek te verbeteren. Thans wil ik nog stilstaan bij de vraag welk rechtsvergelijkend onderzoek zou moeten worden verricht. In het perspectief van mijn vorige opmerkingen is het antwoord op deze vraag in eerste instantie uitermate simpel. Het komt mij voor, dat men bijzonder goede redenen moet hebben om bij een iets groter onderzoek (zoals bijvoorbeeld ter voorbereiding van een dissertatie) geen rechtsvergelijkend onderzoek te verrichten. Ilet afzien van een rechtsvergelijkende dimensie is onderzoeken met oogkleppen op. Uit dit standpunt blijkt, dat een rechtsvergelijkende dimensie bij wrijwel elk researchproject op zijn plaats is. De onderwerpen die (rechtsvergelijkend) onderzocht dienen te worden zijn ondermeer de themata die legislatief actueel zijn, doordat wetswijzigingen worden overwogen. We kunnen constateren, dat ten behoeve van de voorbereiding van wetsontwerpen inderdaad niet zelden gebruik wordt gemaakt van rechtsvergelijking. In de literatuur is daaraan de nodige

94. De op thet woorgestelde dochumentatecentrum betrekkng hebbende gedachten heb ik uitgewerkt na een gesprek met de Maastrichtse advocaa M. J.M. Tripels, oud-hid van do Tweede Kamer. 
aandacht besteed. ${ }^{95}$ Polak ${ }^{96}$ heeft er recentelik nog eens op gewezen, dat in de regel echter niet van vetantwoorde rechtsvergelijking kan worden gesproken. Ambtenaren ten departemente sprokkelen gegevens bijeen of winnen - vaak wia diplomatieke kanalen - informaties in. Hij stell vervolgens, dat nieuwe wegen zouden moeten worden ingeslagen en dit rechtsvergelijkende werk aan de 'universiteiten en met name de leden en vakgroepen van de juridische faculteiten' zou moeten worden uitbesteed. Ook de gedachten van de minister van justitie gaan kennelijk in deze richting, waar hij op een vraag van een kamerlid naar de wenselijkheid de anonimiteit van de donor bij kunstmatige inseminatie op te heffen, zoals in Zweden en West-Duitsland het geval is, onlangs de - ook door Polak aangehaalde woorden sprak: "I $\mathrm{k}$ will nagaan of thet mogelijk is een universiteit voor het verrichten van een dergelijk onderzoek te interesseren'.

Ik meen te kumnen stellen, dat universiteiten - althans onze faculteit deze rechtsvergelijkende research graag zullen verrichten. Dit onderzoek kan echter op verschillende niveaus en met uiteenlopende omvang geschieden. Denkbaar is om studenten afstudeerscripties te laten schrijven over zulke legislatief actuele themata. Mogelijk is echter ook om leden van de tijdelijke of vaste wetenschappelijke staf met zulk onderzoek te belasten, of nieuw aan te trek ken medewerkers onder leiding van stafleden. In het laatste geval is duidelijk, dat een universiteit een dergelijke onderzoeksopdracht nagenoeg alleen kan accepteren, indien het verantwoordelijke ministerie bereid is om de formatieuitbreiding financieel te ondersteunen. Mutatis mutandis geldt tegenwoordig - spijtig genoeg - hetzelfde voor door de wetenschappelijke staf te verrichten onderzoek. De huidige door het ministerie van onderwijs gewenste onderzoeksstructuur laat nauwelijks toe, dat onderzoekers de projecten waarbinnen zij werken verlaten, om pro deo onderzoek te verrichten dat een ministerie opportuun vindt, hoe graag stafleden dit wa arschijnlijk ook zouden doen. In beginsel is er derhalve binnen de

95. Zie voor Nederland: W. Duk, Wetgewing en rechtswergelijking, Preadvies Nederlandse Vereniging voor Rechsvergelijking. Deventer 1984: J.M. van Dunné, The use of comparative law by the Jegistar in the Netheriands, Netherlands reports to the eleverth International congress of comparative law, Deventer 1983, blz. 37 e.v.; D.C. Fokkema, De invloed van de rechsvergelijking og de ont wikkeling wan het nieuwe BW, NJB 1983, b|z. 1223-1227. G.J.W. Steenhof, Naar en Europees privatredn, in: J. B.J.M. ten Berge e.a. (red.). Recht als norm en als aspiratie, Nijmegen 1986, blz. 90-97. Zie werder: Utrich Drobnig/P. Dorflel, Die Nutung der Rechtsvergleichung durch den deutschen Gesetzgeber, Rabels2 1982, blz. 253.307; Bernhard Grolfeld, Vom Beitrag der Rechtsvergleichung zum dentschen Recht, AcP 1984, blz. 296, 297; GroBfeld, Mach und Ohmmacht, blz. 37-44; Jan Kropholler, Whssenschaft und Rechtsvergleichung, Zeitschrift für vergleichende Rechtswissenschaft 1986, blz. 144, 145: Zweigert/Kötz 1, blz. 17-19.

96. J.M. Polatk. Wetgeving en rechtsvergelijking, NJB 1989 , blz. $816,817$. 
universiteiten grote bereidheid on door rechtsvergelijkend onderzoek mee te denken over probleemgebieden, waarop ministeries wetsontwerpen overwegen. Over de randwoorwaarden waaronder zulk onderzoek structureel kan plaatsvinden is nader overleg gewenst. Ministeries zouden daarbij ook moeten overwegen, of het niet verstandig is om universiteiten tevens. permanente opdrachten te geven om met betrekking tot bepalde rechtsgebieden en toegespitst op bepaalde rechtssystemen informaties te fourneren over belangrijke jurisprudentiele en legislatieve ontwikkelingen in het buitenland. Rechtsvergelijkende gegevens over problemen, watrover in beginsel reeds is besloten om legislatief actief te worden, zijn onmiskenbaar van groot belang. Van minstens even grote waarde is het evenwel om bijtijds te signaleren welke problemen in het buitenland aanleiding vormden tot opzienbarende rechtspraak of wetgeving. Onze overheid kan dan - op deze manier getipt - legislatief anticiperen, indien kan worden aangenomen, dat de desbetreffende problemen zich ook in Nederland zouden kunnen voordoen.

Dames en heren, Ik heb $U$ vandatag mijn visie over en mijn voornemens op het gebied wan de rechtsvergelijking geschilderd. Mijn relaas was programmatisch en derhalve niet 'gezellig verhalend'. U had er m.i. echter recht op dat ik mijn programma door middel van deze rede expliciteerde ${ }^{97}$, zodat $\mathrm{U}$ enerzijds wellicht mij kunt trachten te overtuigen tot amendering op enkele punten en anderszijds ook kunt checken, of ik mij ook aan mijn goede voornemens houd. In verband met dit laatste herinner ik eraan, dat mijn medische collega Knottnerus op 29 september 1988 in deze aula in zijn oratie ${ }^{98}$ heeft gesteld, dat elke hoogleraar ertoe zou moeten worden verplicht tenminste eenmaal in de vijf jaren een nieuwe oratie te houden, waarin hij ondermeer - ik stel het in mijn eigen woorden - de evolutie van zijn denken over zijn vakgebied, alsmede de recente ontwikkelingen op dat vakgebied evalueert. Ik zou dit voorstel in beginsel willen ondersteunen. De clausulering 'in beginsel' hanteer ik hierbij uitsluitend derhalve, daar ik mij er van bewust ben, dat de uitvoering ervan wellicht cen overbezetting van deze aula tot gevolg zou kunnen hebben. Doch in elk geval acht ik een voortgangsevaluatie van de inhoud van mijn rede over circa vijf jaar op zijn plaats. U mag mijeraan houden. Ik hoop, dat Uw conclusie dan tenminste een 'Doorgaan maar beter'99 zal zijn.

97. Het is immers vanouds de functie van een eerste openbare les van en nieuwe hoogleralar, zich uit te spreken over zijn woornemens en bedoelingen. Zo Zwalve, blz. 4 .

98. J.A. Knotl nerus, Dialectiek wan het onderzoek in de hüsartsgeneeskunde, ina agurele rede Rijksuniversiteit Limburg, Maastricht 1988.

99. Onder de titel 'Doorgaan maar beter" verscheen vande hand van Job Cohen op 3 april 1986 een intern evaluatierapport over de in Maastricht gehanterde onderwijsmethode. 
Bijna aan hel eind van deze oratio pro domo ${ }^{100}$ gekomen, past het diegenen dank te zeggen, die ertoe hebben bijgedragen, dat ik in deze functie ben benoemd. Het College van Bestuur van de Rijksunversiteit Limburg dank ik voor het in mijgestelde vertrouwen. Naar ik van harte hoop, zal het College uit deze oratie wilten concluderen, dat ik mij zal insparnen mijn taak naar beste weten en kunnen te vervullen.

Gestudeerd heb ik aan de Rijksuniversiteit te Groningen en daar begon ook mijn academische loopbaan. Zonder enige twijfel hebt $U$ - waarde Brahn eerst als docent en later als chef zeer grote invloed uitgeoefend op mijn doen en denken. I $k$ ben $U$ voor $U w$ inspiratie en inspanningen zeer erkentelijk en ben blij $U$ daarvoor vandaag in het openbaar te kunnen danken. Met name ben ik ook dankbaar voor het feit, dat U mij - tesamen met Uw collegaproximus Brunner - steeds alle ruimte hebt gegeven om naast mijn werkzaamheden op het gebied van het burgerlijk recht - waarvoor ik in Groningen eigenlijk was benoemd - me nader te oriënteren en te verdiepen in de rechtsvergelijking en het internationaal privaatrecht. Zonder die ruimte zou ik hier wandaag niet staan, althans niet met de onderhavige leeropdracht.

Wiarda, Jessurun d'Oliveira en Großfeld hebben mijn eerste stappen op het gebied van de rechtswergelijking en het internationale privaatrecht begeleid. Zij hebben mij zo enthousiast gemaakt voor deze vakken, dat ik nu - naar ik ten stelligste hoop - in staat ben andere personen op deze gebieden to enthousiasmeren en te begeleiden. Met name mijn postdoctorale verbliff aan de Westfälische Wilhelmsuniversitäl te Münster in Westfalen en in het bijzonder in het door Großfeld geleide Institut für internationales Wirtschaftsrecht is voor mijn wetenschappelijke ontwikkeling van doorslaggevende betekenis geweest. Mijn belangstelling voor vele onderwerpen, waarover ik later heb gepubliceerd - waaronder het nationaliteitsrecht is destijds gewekt. Ik hoop en verwacht vanuit mijn nieuwe functie nauwe contacten te mogen blijven onderhouden met diegenen die mij in de eerste geheimen van mijn vakgebieden hebben ingewijd. Ik zou het fujn winden, indien wij soms aan gezamenlijke projecten zouden kunnen werken. Ik ben er zcker van, van $\mathrm{U}$ te kunnen blijven leren.

Waarde leden van de vakgroep Burgerlijk Recht aan de Rijksuniversiteit te

100. Vgl. Güner Frankenberg, Critical comparisons: rethinking comparative law, Harvard International Law Journal 1985 , blz. 420 , in wiens ogen deze toespraak ongetwijeld een manifestatie van een "Rewersed Cinderella Complex" zal zin. 
Groningen. Ruim zeven jaren heb ik in Uw midden mogen werken, ruim zeven jaren zijn sindsdien verstreken. Niettemin verbinden ons nog steeds warme banden van herinnering en sympathie. lk ben blij wandaag zovelen Uwer hier in deze zaal aanwezig te mogen zien en hoop ook in de toekomst op een intensieve en sympathieke samenwerking van Uw vakgroep met de vakgroep waarvan ik thans deel uitmaak.

Waarde leden van het wetenschappelijk en niet-wetenschappelijk personeel van de faculteit der Rechtsgeleerdheid van de Rjjksuniversiteit Limburg. Het is een fijn voorrecht om te mogen werken in een ambitieuze faculteit, waarin alle ideeen die men heeft bespreekbaar zijn en nog niets is vastgeroest. Dit geldt met name voor iemand met een leeropdracht in vakgebieden, die thans over het algemeen nog niet tot de kernvakken van een rechtenstudie worden gerekend, maar - sta mij enige inaugurale arrogantie toe - dit in de komende eeuw zeker zullen worden. Sinds 1982 ben ik nu in deze faculteit werkzaam, zij het met privaatrecht als primair aandachtsveld. Met een nieuwe opdracht en daarmee verbonden fris élan mag ik nu in Uw midden blijven. Ik doe dat met veel plezier, daar ik de wetenschappelijke en persoonlijke sfeer tussen de collegae hier aangenaam vind. Bijzondere vermelding verdient op deze plaats Cees Flinterman, die vandaag bijna een jaar geleden in deze aula als mijn promotor optrad.

Gezien mijn leeropdracht was een indeling bij de vakgroep Metajuridica of zelfs bij de vakgroep Internationaal Recht niet ondenkbaar geweest. Niettemin ben ik ingedeeld bij de vakgroep Privaatrecht. Binnen die vakgroep ben $i k$ - qua opdracht - een ietwat vreemde eend in de bijt. Het is fijn en goed, dat $U$ - leden van de vakgroep privaatrecht aan de Rijksuniversiteit Limburg - mij dat niet laat merken, doch in tegendeel mij de vakgroep in vele zettingen laat vertegenwoordigen.

Lieve Hildegard, thans wil ik het woord tot jou richten. Het feit, dat jij Duits juriste bent, leidt er toe, dat mijn eigenlijke rechtsvergelijkende werk dikwijls voor en na de gebruikelijke kantooruren in discussies met jou plaatsvindt. Jij stimuleert mij en denkt - meer dan enig ander - met mij mee over de wetenschappelijke - en ook andere - problemen die mij bezighouden. Het feit dat jij hier aan de Rijksuniversiteit Limburg werkt op het gebied van het Europese recht en het volkenrecht, bewerkstelligt dat ik via jou gemakkelijk toegang heb tot vakgebieden, die ik als goede en invloedrijke buren van internationaal privaatrecht en rechtsvergelijking beschouw. Het is een voorrecht en geluk om met jou te mogen samenwerken en met jou en David te mogen samenleven.

Dames en Heren studenten; naar ik hoop, hebt U uit mijn toespraak kunnen 
concluderen, dat geen hedendaags jürist en zeker geen enkel jurist met enige academische ambitie het zonder tenminste een basisorientatie op het gebied van de rechtsvergelijking kan stellen. Door de nog steeds toenemende internationalisering worden wanden tussen de rechtsstelsells steeds sterker poreus. De osmose tussen de rechtssystemen intensiveert. Wie dit tracht te ontkennen en derhalve het belang van rechtsvergelijking poogt te negeren, zal in theorie en praktijk slechts matige resultaten kunnen boeken. Hetzelfde geldt trouwens voor het international privaatrecht, waarover ik vandaag nog niets heb gezegd. De relevantie wan het IPR kan hier in Maastricht, waar de geografisehe grenzen van ons rechtssysteem binnen enkele minuten bereikbaar zijn, niet worden ontkend. Op de gebieden van de rechtsvergelijking en het international privaatrecht zal ik U naar beste weten en kunnen wegwijs proberen te maken. Ik hoop dat goed te doen, maar herinner $U$ aan het einde van deze toespraak gekomen nogmaals aan de woorden van de apostel Paulus aan de gemeente te Thessaloniki - ditmaal in een correcte vertaling - : Toetst alles en behoudt het goede.

Ik heb gezegd. 


\section{Lijst van verkort geciteerde literatuur}

Arminion/ Noldet Wolt

Bogdinn

Constantinesico

David

Ebert

Gorle/Bourgeois/ Bocken

Grobfeld, Macht und Ohnmacht

Hilf

Kokkini-Iatridou

Kokkinimatridou, Preadvies

Kropholler

Rheinstein

Rodicre

Satureplante

Sauveplanne. Preadvies
Plerte Arminjon/Boris Nolde Martin Wolf, Trate de drout compare. 3 delen, Paris $1950 / 1951$

Michael Bogdan, Komparativ rät, Lund 1978

Leontin-Jean Constantinesco. Rechsvergletiung, 3 defen, Koln eto. $1971 / 1972 / 1983$

Rene David, Les grands systemes de droit contemponatn, sste druk, Paris 1982

Kurt Hanns Ebert, Rechtswergleichung. Einfwhrang in die Crundiagen. Bern 1985

Frits Gorlé/Greta Bourgeois/Hubent Bocken. Rechtsuergehliking. Gent 1985

Bernhard Orobfeld. Machu and Ohnmach der Rechtsvergleichung. Thibingen 1984

Meinhard Hilf, Comparative law and European Law, in Lncyclopedia of Public International Law, vol. $10,612,45-59$

D. Kokkini-latridou e.a., Een inleiding tot het rechtsvergelijkende onderzock, Deventer 1988

D. Kokkini-latridou, Enkele methodologische aspecten van rechtsvefgelliking. Het derde deel van een (pre-)paradigma, Preadvies yoor de Nederlandse vereniging voor rechtsvergeliking. $\mathrm{Nr}$. 36, Deventer 1985

Jan Kropholler, Comparative law, function and methods, in: Encyclow pedia of Public International Law, vol. 10, blz. $52-57$

Max Rheinstein, Einfihrung in die Rechtsvergleichung, 2de druk, München 1987

Rene Rodiere. Introduction au droit compare, Paris 1979

Jean Georges Sauveptanne, Rechisstelsels in vogelvicht, 2 de druk, Dewerter 1981

Jean Georges Sauveplanne, De mothoden wan privatuechtelijke rechtswergeliking, Preadvies woor de Nederlandse verchiging voor rechtsvergelijking, Nr: 20 , Deventer 1985

Schwarz-liebermann H.A. Schwarz-Liebermann von Wahlendor, Droit compare, Paris von Wallendorf 1978

Solá Cañizares
Felipe de Solá Cañzares, Iniciación al estudio del derecho comparado. Bareelona 1954 
Zwalwe

Zweigeri/Kots

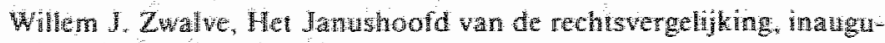
rate rede Cromingen 1988

Konrad Zweigert/Aein Kotz. Eintithrung in die Rechswergleichung auf dem Gebicle des Privatrechts, 2 de druk, 2 delen. Thbingen 1984 